\title{
Couro imperial Raça, travestismo e o culto da domesticidade
}

Anne McClintock ${ }^{* *}$

\section{Resumo}

Analisando a relação sadomasoquista de um casal vitoriano, a autora argumenta que o travestismo de Hannah Cullwick e seu fetichismo eram tentativas sistemáticas de negociar os perigos do que, segundo ela, foi um dos atos de desaparecimento mais bem sucedidos da história moderna - a ocultação do trabalho doméstico das mulheres. Recusando-se a trocar a sua força desordeira da classe trabalhadora pelas rédeas da respeitabilidade, Hannah se adornou com seus próprios grilhões simbólicos, pondo em questão, de modo dramático, a narrativa vitoriana de progresso e a família humana heterossexual.

Palavras-chave: Fetichismo, Sadomasoquismo, Trabalho Doméstico, Era Vitoriana.

\footnotetext{
* Imperial Leather. Race, Cross-Dressing and the Cult of Domesticity, capítulo 3 do livro Imperial Leather: Race, Gender and Sexuality in the Colonial Contest. New York, London, Routledge, 1995, pp.132-180. O Comitê Editorial dos Cadernos Pagu agradece a autorização da Routledge para traduzir este capítulo. [Tradução: Plinio Dentzien.]

${ }^{* * *}$ Universidade de Wisconsin. www.wisc.edu
}

cadernos pagu (20) 2003: pp.7-85. 
Couro imperial

Imperial Leather.

Race, Cross-Dressing and the Cult of Domesticity

\begin{abstract}
Analyzing the $S \backslash M$ relationship of a Victorian couple, the author argues that Hannah Cullwicks'travestism and fetichism were a sustained attempt to negociate the perils attending the Victorian erasure of women's work - one of the most successful vanishing acts of modern history. Refusing to barter her unruly working-class strength for the halter of respectability, she decked herself in her own symbolic chains and threw dramatically into question the Victorian narrative of progress and the heterosexual Family of Man.
\end{abstract}

Key Words: Fetichism, Sadomasochism, Domestic Work, Victorian Age. 
Anne McClintock

Esposa e empregada são iguais, só se distinguem no

nome

Lady Chudleigh

A esposa tornou-se a chefe das criadas.

Friedrich Engels

Em maio de 1854, aos 25 anos, Arthur Munby parou uma criada na rua [Fig.3.1]. O encontro foi tão casual como todos os que aconteciam nas andanças de Munby, mas a mulher estava destinada a se tornar sua companheira de toda a vida e esposa. Quase imediatamente, Hanna Cullwick e Arthur Munby passaram a viver um intenso e clandestino caso de amor que durou pelo resto de suas vidas. Depois de dezenove anos, casaram em segredo, embora tivessem vivido na mesma casa por apenas quatro anos e ainda assim, na aparência, como patrão $e$ empregada.

Tanto Cullwick como Munby registram em seus diários que desde o começo se sentiram destinados um ao outro. ${ }^{1}$ Num certo sentido, não foi por acaso que a criada e o advogado se encontraram na rua. $\mathrm{Na}$ multidão promíscua - esse elemento permanentemente à beira da confusão social - as classes se misturam, estranhos se tocam, homens e mulheres se encontram $e$ desencontram. Como escreve Benjamin: "Uma rua, uma conflagração ou um acidente de trânsito reúnem pessoas que não se definem em termos de classe". ${ }^{2}$ Cullwick e Munby se

\footnotetext{
${ }^{1}$ Cullwick escreve que, antes de encontrar Munby, Deus lhe mostrara a face dele numa visão de fogo. Munby também estava exultante: "Em 26 de maio de 1854, ela me foi trazida... por quem trouxe Eva para Adão." STANLEY, Liz. The Diaries of Hannah Cullwick: Victorian Maidservant. New Brunswick, Rutgers University Press, 1984, p.1. MunBy. Diary. In: Hudson, Derek. Munby, Man of Two Worlds; the ILfe and Diaries of Arthur J. Munby 1812-1910. Cambridge, Gambit, 1974, p.76.

2 Benjamin, Walter. Charles Baudelaire: a Lyric Poet in the Era of High Capitalism. London, Verso, p.62.
} 


\section{Couro imperial}

alimentavam da multidão, colocando sua estranha vida de fantasia nas margens dos limites sociais - raça e gênero, trabalho pago e não pago, domesticidade e império. Seu senso de destino, além disso, dá testemunho da força social dos éditos vitorianos que eles tão escandalosamente desprezavam em privado e tão decorosamente afirmavam em público. Ao mesmo tempo, o encontro casual e proibido por ultrapassar os limites sociais se revela um tema recorrente no fetichismo doméstico e racial que estrutura suas vidas e de fato, estrutura a sociedade vitoriana como um todo.

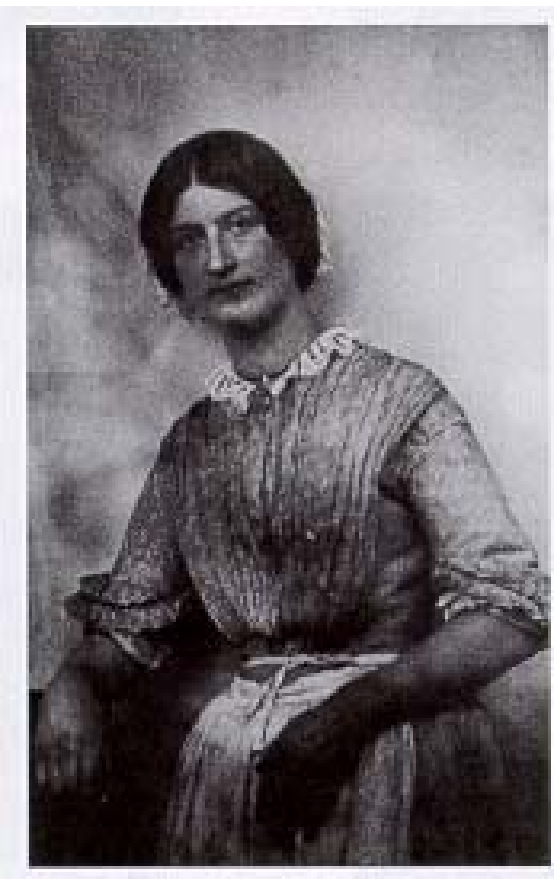

Figure 3,1 Hankar Cullwick.

Fig. 3.1. Hannah Cullwick 
Anne McClintock

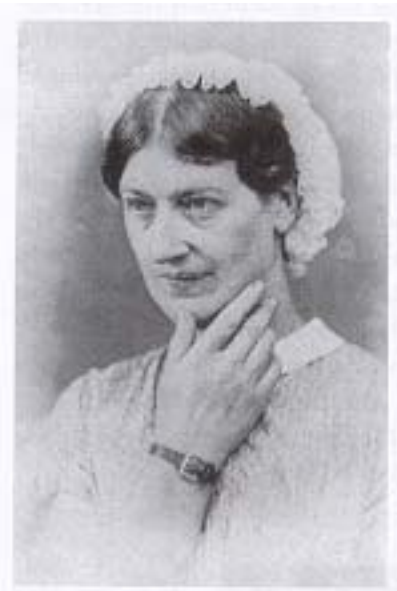

Figute 3.2 The SLave, Band

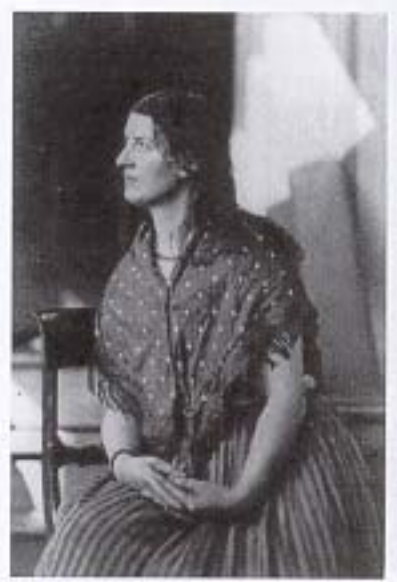

FigUne.3.4 Noturse to USE Bur Hru Chasns

Fig.3.2. A pulseira de escrava. Fig.3.4.Nada a usar a não ser seus grilhões.

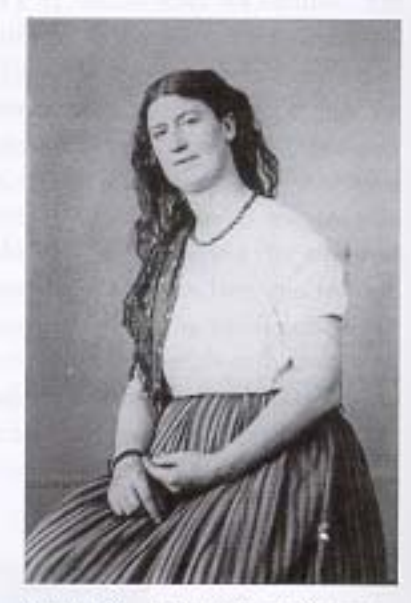

FNSURE 3.3 FITISHISU ON DISPLAY.

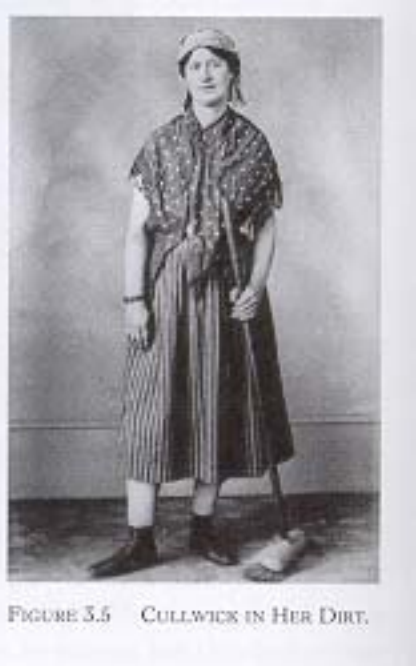

Fig.3.3. O fetichismo exibido. Fig.3.5. Cullwick na faxina. 


\section{Couro imperial}

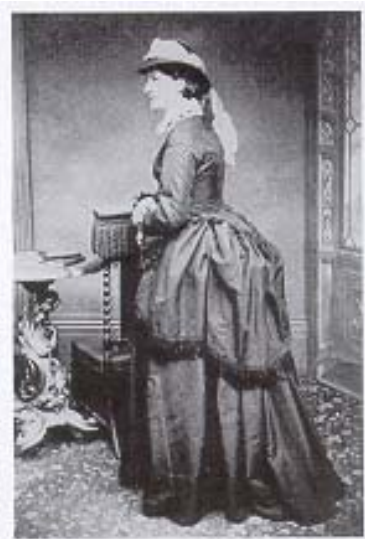

Ficuies 3.6 Culiwick Croos. Dresseis as a Lasor

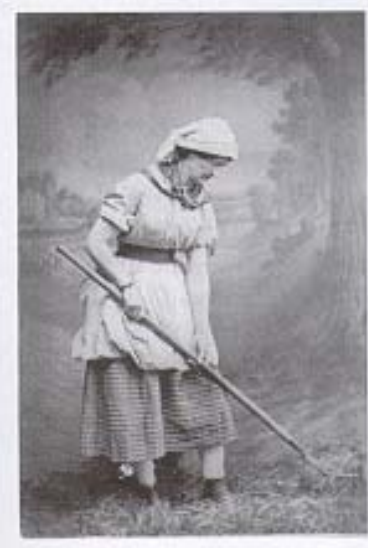

Praure 3.8 Cunwick Cross. Derssed IS A FARS WORKER

Fig.3.6. Cullwick disfarçada de dama.

Fig.3.8. Cullwick disfarçada de trabalhadora rural.

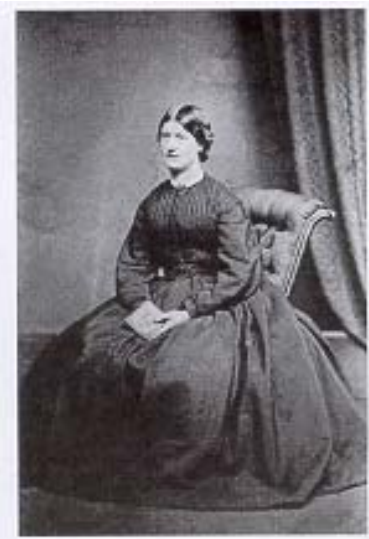

Ficure 3.7 Clus TuLsvestas.

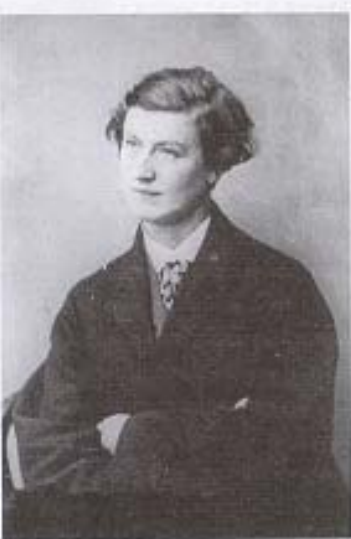

Figtire 39 Gender Passinc: CuLLWick As a MaN.

Fig.3.7. Travestismo de classe.

Fig.3.9. Travestismo de gênero: Cullwick como homem. 


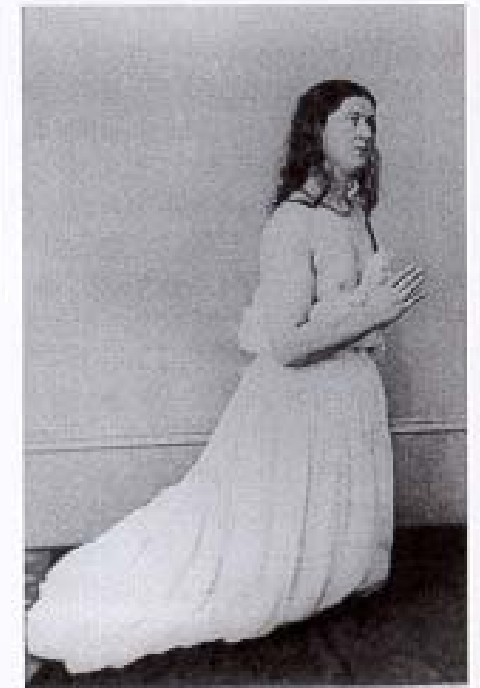

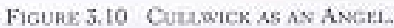

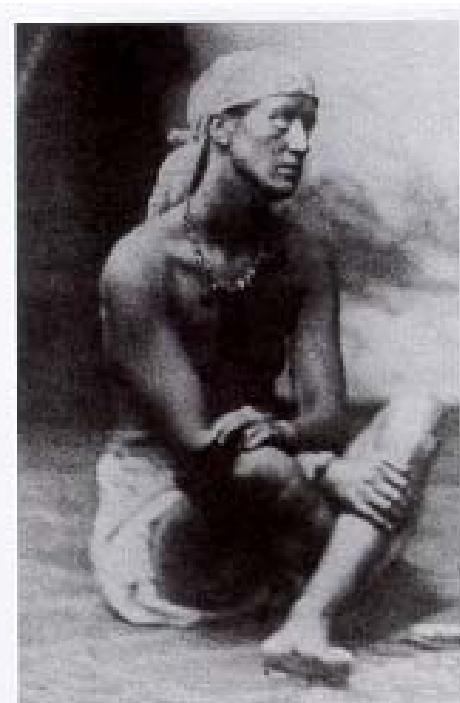

Ficlige 3.11 RACE AND GENDER TRANSYKSTISM: CULLWICE as A MLLE SLAVE.

Fig.3.10. Cullwick como anjo.

Fig.3.11. Travestismo de raça e gênero: Cullwick como escravo.

Leonore Davidoff evoca de maneira vívida os jogos e rituais fetichistas que Cullwick e Munby encenavam para seu mútuo prazer quando juntos e reviviam em seus diários quando separados. ${ }^{3}$ Munby retirou mais tarde de seus diários os detalhes do "treinamento" que afirma ter dado a Cullwick, mas sabemos

${ }^{3}$ DAVIDOFF, Leonore. Class and Gender in Victorian England. In: NEWTON, Judith I., RYAN, Mary P. e WaLKOWITZ, Judith R. (eds.) Sex and Class in Women's History. London: Routledge \& Kegan Paul, 1983, p.16-71. Ver também o excelente trabalho de Davidoff a respeito das relações domésticas em Above and Below Stairs. New Society 26, 1973, pp.181-183 e Mastered for Life: Servant and Wife in Victorian and Edwardian England. Journal of Social History 7, 1974, pp.406-28. Estou em dívida, neste texto, para com o trabalho de Davidoff e também com seu trabalho pioneiro em colaboração com HALL, Catherine. Family Fortunes: Men and Women of the English Middleclass, 1780-1850. London e Chicago, Hutchinson e Chicago University Press, 1987. 
Couro imperial

que ela se dirigia a ele pelo título imperial de "Massa"* e que usava uma "pulseira de escrava" no pulso e uma corrente em volta do pescoço (cuja chave ficava em poder de Munby) como prova de sua "servidão" [Figs.3.2-3.4]. Sabemos que ela se ajoelhava, lambia-lhe as botas e lhe lavava os pés para confessar seu amor e servidão. ${ }^{4}$ Ela posou para muitas fotografias: como a trabalhadora que era "na faxina"; disfarçada como dama de alta classe; como jovem camponesa, homem, anjo, escravo e, "quase nua" e enegrecida da cabeça aos pés, como limpador de chaminés [3.5-3.11].

Quando casaram em segredo dezenove anos mais tarde, disfarçou-se de dama de alta classe e viajou com Munby pela Europa. De volta a Londres, daria um jeito de esfregar teatralmente ajoelhada a entrada da casa enquanto Munby andava pela rua a balançar languidamente sua bengala [Fig.3.12]. Ele ia à pensão na qual ela trabalhava para ser servido por ela como se fossem estranhos, para depois encontrá-la nas colinas próximas, saboreando em segredo entre beijos e risadas o conhecimento da ligação proibida. Quando viviam em casas próximas, Cullwick freqüentemente visitava Munby em roupas de faxina, depois de um exaustivo dia de trabalho, com as roupas úmidas e sujas, o rosto deliberadamente escurecido com graxa de sapatos, as mãos vermelhas e ásperas; apenas para aparecer mais tarde na mesma noite vestida como dama de alta classe em limpa elegância. Passavam horas divertidas lembrando a provação do trabalho dela, e contando e recontando ritualisticamente a incrivel quantidade de botas que ela limpava. Num par de ocasióes na casa de seu outro empregador, Cullwick tirava toda a roupa com exceção de uma venda nos olhos e trepava pela chaminé, onde se enrodilhava "como um cachorro" na fuligem morna, saboreando

*Forma abreviada de Master, senhor, patrão. [NT]

4 Munby era admirador de Ruskin e as idéias de Carlyle a respeito da elevação moral pela servidão tornaram-se a base do que ele via como seu "treinamento" de Cullwick nas lições de submissão doméstica (ainda que ele não tivesse nenhuma intenção de aplicar os princípios de Carlyle a si mesmo). 
a sensação mais tarde em seu diário, para deleite de Munby. Seu diário revela (e o dele não) que ela também o erguia em seus grandes braços musculosos, embalando-o e "ninando-o" como a uma criança.

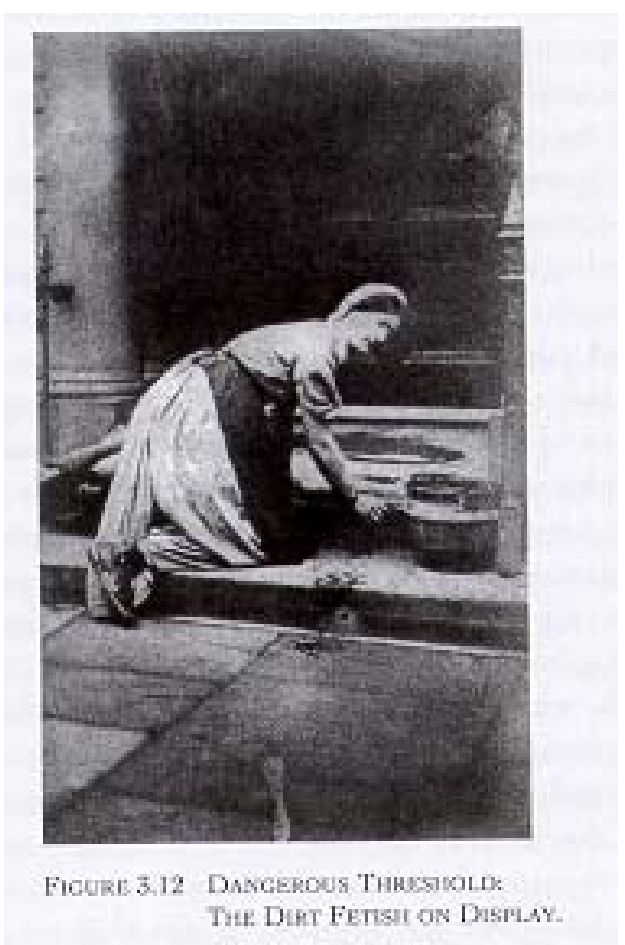

Fig. 3.12. O limiar perigoso: exibição do fetiche da sujeira.

No correr dos anos, Cullwick escreveu um diário volumoso, primeiro a instâncias de Munby, mais tarde por razões próprias mais complexas, em que narrou o regime diário de seu trabalho doméstico e de sua curiosa vida com Munby. Os diários de ambos revelam, embora de maneira diferente, um envolvimento profundo e mútuo numa variedade de rituais fetichistas: escravo/senhor, servidão/disciplina, fetichismos de mão, pé e 
Couro imperial

botina, rituais de lavagem, infantilismo, travestismo e um fascínio mútuo e profundo pela sujeira. Os roteiros de sua vida de fantasia eram fundamentalmente uma transgressão teatral das iconografias vitorianas de domesticidade e raça, e seus rituais fetichistas tomavam forma em torno da afinidade crucial, mas oculta, entre o trabalho da mulher e o império. No que segue, argumentarei que seu fetichismo habitava as margens de uma dupla rejeição da sociedade vitoriana dominante: negação do valor do trabalho doméstico feminino na metrópole industrial e desvalorização do trabalho colonizado na cultura que caía sob o violento domínio imperial. Qual é o significado dos rituais de Cullwick e Munby, fazendo parte como fazem do mundo do fetiche? E, especificamente, qual é a relação entre fetichismo, domesticidade e império?

A definição freudiana do fetiche atribui normalidade privilegiada à heterossexualidade masculina e à cena da castração. Desejo explorar o fetichismo como um fenômeno mais complexo e historicamente diverso que não pode ser reduzido a uma única narrativa masculina e sexual de suas origens. Quero desafiar a primazia do falo no âmbito do fetichismo e abrir as teorias freudiana e lacaniana do fetichismo a uma história mais complexa $e$ variada em que a classe $e$ a raça desempenham um papel tão formador quanto o gênero.

A principal contradição que anima o fetichismo de Cullwick e Munby é, sugiro, a dicotomia histórica entre o trabalho pago da mulher e seu trabalho não pago em casa - sobredeterminada pelas contradições do racismo imperial e negociada pelas iconografias fetichistas de escravo e senhor, sujeira e limpeza, rituais de reconhecimento e travestismo. Em contraste com a idéia do fetichismo como reserva tipicamente masculina, Cullwick assume o seu lugar entre as incontáveis mulheres para as quais o fetichismo era uma tentativa - ambígua, contraditória e nem sempre bem sucedida - de negociar os limites do poder de maneira que resultasse em algo mais do que simples lições sobre domínio e submissão. 
O fetiche, que vive no limite entre o social e o psicológico, põe em relevo a irrelevância de separar os domínios da psicanálise e da história social. Tanto a psicanálise como o marxismo se formaram em torno da idéia do fetichismo como uma regressão primitiva e a rejeição do valor social do trabalho doméstico e é, portanto, apropriado que as inclinações fetichistas de uma obscura criada nos obriguem a começar a renegociar uma vez mais a relação entre a psicanálise e a história social, a agência das mulheres e o poder masculino, a domesticidade e o mercado.

$\mathrm{O}$ que segue é menos uma tentativa de recuperar empiricamente o passado do que uma tentativa de intervir estrategicamente em narrativas históricas de raça e de fetichismo, de domesticidade e império, de modo a por em questão não só a força histórica dessas relações na Inglaterra vitoriana, mas também suas implicações que continuam em nosso tempo.

\section{Sem pigmalião Agente ambíguo}

Tanto Munby quanto seu biógrafo Derek Hudson descrevem Cullwick como uma marionete rústica, embora encantadora, um ser curioso treinado, vestido e controlado por seu "Massa", tropeçando em seus desajeitados movimentos teatrais para satisfazer a vontade dele. ${ }^{5}$ Anos depois, Munby diria que fora ele que ensinara a Cullwick o trabalho servil: "treinandoa e ensinando-lhe" os "[trabalhos] mais baixos \& servis", iniciando-a na subserviência e nas indecorosas degradações de seu amor. ${ }^{6}$ Quando Cullwick se recusou a "entrar na sociedade" como sua esposa, Munby lamentou que ela tivesse se adaptado bem demais ao "treinamento" e se casado para sempre com o

${ }^{5}$ Hudson reconhece que os diários de Munby são tanto dela quanto dele, mas na seqüência ignora os dela e, de fato, apaga a perspectiva de Cullwick.

${ }^{6}$ MunBy. Diary, 19 de julho de 1894. Apud STANLEY, L. The Diaries of Hannah Cullwick... Op. cit., p.12. Munby tirou as descrições desses "treinamentos" de seus diários. 
Couro imperial

trabalho servil. Cullwick é vista de maneira semelhante por Hudson como pouco mais que o "produto do treinamento (dado por Munby) a ela sobre os meios da salvação pela lida diária".? Em conseqüência, Hudson acha que os diários e cartas de Cullwick não merecem "mais que uma breve olhada". Até Leonore Davidoff, num excelente ensaio, apresenta um retrato parcial da relação entre eles e vê Munby como o mestre de cerimônias da vida de Cullwick, o empresário e coreógrafo de seus rituais, Svengaly de seu Trilby. E assim Hudson e Davidoff se tornam cúmplices da visão auto-congratulatória do próprio Munby que se vê como Pigmalião, esculpindo como se o fizesse na pedra os valores de Cullwick e instilando nela uma "devoção ao trabalho servil". "De muitas maneiras", escreve Davidoff, "Hannah foi, de fato, uma criatura de sua fantasia". ${ }^{9} \mathrm{Na}$ visão de Davidoff, a relação deles era dirigida "nos termos dele e, em última análise, a um preço muito alto". "Tudo acontece", escreve ela, "pela vontade do protagonista de classe média, que cria a situação $e$ constrói a transformação". ${ }^{10}$ Uma vez mais, a criada desaparece da narrativa de classe média. ${ }^{11}$

Numa excelente introdução aos diários de Cullwick, Liz Stanley protesta contra esses retratos condescendentes $e$ pejorativos de Cullwick. Aceitar apenas o lado Munby do assunto, vendo Cullwick como não mais que a criação de Munby nos faz correr o risco de aceitar "o pensamento vitoriano classista e sexista como um reflexo acurado do mundo social como ele realmente era". Ao contrário, diz ela, os escritos de Munby "são

\footnotetext{
7 Hudson, D. Munby, Man of Two Worlds... Op. cit., p.70.

8 ID., IB., p.4.

9 Davidoff, L. Class and Gender... Op. cit., p.58.

${ }^{10}$ ID., IB., pp.38, 40.

${ }^{11}$ Vale a pena observar que todos esses críticos tratam Munby como adulto, referindo-se a ele como Munby, ao passo que Cullwick é infantilizada, sendo-lhe negado estatuto social pleno quando a referem apenas como "Hannah".
} 
freqüentemente desmentidos pela realidade da experiência". ${ }^{12}$ Eles são certamente desmentidos pelas perspectivas freqüentemente contrastantes de Cullwick. Há em seu diário e no de Munby ampla evidência, se os lemos a contrapelo, de que Cullwick inventou tantos cenários e concebeu tantos roteiros como o próprio Munby. É também claro que ela teve muito prazer e ganhou algum poder fazendo-o, a despeito da óbvia desvantagem de sua situação. Longe de limitar-se a ser uma trabalhadora braçal passiva, ela protegia teimosa e firmemente seus próprios interesses e resistia a Munby quando suas necessidades entravam em conflito com as dele. O retrato crítico de Cullwick como uma triste mulher sem valor e objeto de brincadeiras abusivas apenas serve para anular o auto-respeito e a atuação que ela lutou tanto e tão teimosamente para preservar, em circunstâncias extremamente limitadas. De fato, a supressão da resistência de Cullwick durante toda sua vida à limitação produz uma triste ironia, pois poder-se-ia dizer que o projeto que animava sua vida obscura e árdua era o projeto do reconhecimento social do trabalho doméstico feminino.

Certamente não foi Munby que iniciou Cullwick no ambíguo valor do orgulho no labor da classe trabalhadora, pois a mãe dela e sua comunidade de trabalhadores, a igreja, a escola de caridade, o vilarejo e a mansão próxima já tinham conformado os fundamentos de sua identidade e de suas atitudes para com o trabalho. Considerar Munby como o único e original formador da identidade seria capitular a uma fantasia vitoriana dominante na classe média: a fantasia da supervisão e do controle masculinos e filantrópicos sobre as vidas das mulheres da classe trabalhadora. A relação de Cullwick com Munby era inevitavelmente informada pela discrepância entre seu considerável poder dentro da relação $e$ sua impotência social fora dela, discrepância que Munby não deixava de explorar quando podia.

Não quero, porém, dar a impressão de que a relação de Cullwick com Munby era de igualdade libertária e de poder

${ }^{12}$ StAnley, L. The Diaries of Hannah Cullwick... Op. cit., p.11. 
Couro imperial

mútuo; tal noção não se sustenta. Estou antes interessada na questão mais difícil - que tipo de atuação é possível em situações de desigualdade social extrema. A vida de Cullwick expressa uma forte determinação de negociar o poder numa circunstância de grandes limitações, de maneiras que levantam questões não em relação a suas relações entre gêneros e entre classes com Munby, mas também sobre suas relações entre gêneros e entre classes com suas empregadoras. Dentro das casas, o peso desigual do trabalho das mulheres, as recriminações mútuas, o assédio de classe $e$ as rebeliões de classe tinham lugar dentro de uma combinação de afastamentos de classe e intimidades de gênero. Em uma palavra, um dos principais interesses deste capítulo é explorar a tensão estratégica entre as limitações sociais e a atuação social.

No que segue, quero questionar uma tendência feminista a ver as mulheres como vítimas não ambíguas, tendência essa que iguala atuação e contexto, corpo e situação, anulando assim a possibilidade de recusa estratégica. Desse ponto de vista, Cullwick seria reduzida a uma serviçal vitimizada, exibida como representação da degradação feminina e do domínio masculino. Se ela não foi uma vítima não ambígua, porém, ela também não foi uma heroína não ambígua da revolta feminina. Suas circunstâncias eram constantemente duras e a colocavam em desvantagem; e no entanto, dentro delas, ela se dedicou a uma permanente negociação de poder, pondo em questão as verdades binárias de dominação e resistência, vítima e opressor. Que fazer da atuação e dos desejos de Cullwick nesses curiosos rituais?

A infância de Hannah Cullwick foi a história comum de uma menina destinada por toda a vida ao serviço nas casas dominantes da Grã Bretanha. Filha de uma criada e de um seleiro, nasceu em 26 de maio, 1833, na vila de Shifnal, em Shropshire. Sua mãe, Martha Cullwick, trabalhava para a senhora do Hall e seu pai trabalhava nos estábulos. Seus pais serviam, portanto, ao mundo em extinção da antiga nobreza, onde o poder era investido em terras, $e$ as classes sem terra se relacionavam às classes senhoriais por códigos ancestrais de dever, lealdade $e$ 
paternalismo. Embora Cullwick viesse a morrer na vila em que nasceu, em 9 de julho de 1909, passou sua vida como criada entre as propriedades rurais senhoriais $e$ as casas urbanas da elite manufatureira em Londres e Margate. ${ }^{13}$ Nos estaleiros imperiais, nos bancos mercantis, nas fábricas e moinhos, o poder era investido como capital e nos extensos saques do império, e a classe trabalhadora se relacionava com os novos senhores através da dinâmica pouco confiável do nexo do dinheiro. A vida de Cullwick saltava do mundo decadente da nobreza ao mundo ascendente da manufatura industrial $e$, embora sua infância tenha sido comum em quase todos os aspectos, sua vida atravessaria algumas das mais profundas fissuras da era vitoriana.

Nascida numa cabana rústica em Shropshire, Cullwick passou a maior parte de sua vida nas cidades, trabalhando como encarregada dos urinóis numa estalagem, como empregada num berçário, empregada na cozinha, ajudante de cozinha e faxineira, e uma estranha camponesa nas enormes casas decadentes da elite vitoriana urbana. No apogeu da "mulher desocupada", ela se tornou musculosa com o trabalho braçal. Destinada pela classe a casar com um trabalhador, casou em vez disso com um membro da burocracia da classe média alta. Como mulher de advogado, Cullwick podia ter "entrado na sociedade", mas preferiu viver como criada em meio à sua própria classe, passando muito pouco tempo com seu marido. Numa época em que os serviços da esposa não tinham valor econômico, insistia em que o marido lhe pagasse um salário mensal. Numa época em que a maioria das mulheres dedicava dois terços da vida a criar filhos, ela não os teve. Quando a maioria das mulheres da época era analfabeta, ela era capaz de ler e escrever e deixou dezessete diários, que oferecem detalhes íntimos dos feitos hercúleos de sua lida doméstica. Sua vida foi comum e sua morte não provocou impacto, mas retrospectivamente seus diários oferecem um testemunho incomum e importante da vida de uma criada

${ }^{13}$ ID., IB., p. 2. 
Couro imperial

vitoriana. Os diários de Cullwick são um testemunho "da última geração de mulheres que fizeram trabalho braçal pesado em grande proporção". ${ }^{14}$

Em 1851 Cullwick viajou para Londres com seus patrões; os ritmos de sua vida seguiam a lógica de classe de suas migrações sazonais. ${ }^{15}$ Em Londres, uma visão no fogo lhe mostrou o rosto de Munby. Em 1854, ela voltou a Londres, onde Munby se aproximou dela na rua. Quando voltou novamente no ano seguinte, encontrou alojamento num quarto pequeno e frio: "Ali Massa voltou a me ver \& foi ali que pela primeira vez escureci meu rosto com óleo \& chumbo". ${ }^{16}$ Instigado por Cullwick, o casal começava sua carreira de vida de fetichismo doméstico e racial e logo depois Cullwick começou a escrever o primeiro de seus dezessete diários.

${ }^{14}$ ID., IB., p.1. Para interpretações a respeito do trabalho das mulheres, e da relação entre o trabalho das mulheres e o desenvolvimento econômico, ver Davidoff, L. e Hall, C. Family Fortunes... Op. cit.; BrancA, Patrícia. Women in Europe since 1759. London, Croom Helm, 1978; ScOTT, Joan e TILLY, Louise. Women, Work and Family. New York, Holt, Reinhardt and Winston, 1978; ALEXANDER, Sally. Women's Work in Nineteenth Century London: a Study of the Years 1820-1850. In: MitCHELl, Juliet e OAKLEY, Ann. (eds.) The Rights and Wrongs of Women. Harmondsworth, Penguin, 1976; BuRMan, Sandra. (ed.) Fit Work for Women. New York, St.Martin's Press, 1979; TAYLOR, Barbara. The Men are as Bad as their Masters...: Socialism, Feminism and Sexual Antagonism in the London Tailoring Trade in the 1830's. In: NEWTON, J., RYAN, M. e WALKOWITZ, J. (eds.) Sex and Class... Op. cit., pp.187-220; DelPHY, Christine. Close to Home: a Materialist Analysis of Women's Oppression. Amherst, University of Massachusetts Press, 1984 [trad. de Diana Leonard]; JoHN, Angela. By the Sweat of their Brown: Women Workers at Victorian Coal Mines. London, Routledge, 1984.

${ }^{15}$ Munby se formou no Trinity College, Cambridge, em 1851, no mesmo ano em que Cullwick chegou a Londres, e se hospedou no Lincoln's Inn em junho. Nos cinco anos seguintes ele viveu em pensões $e$ a seguir ocupou as peças do primeiro piso de Three Court in the Temple em 1857, onde viveria até sua morte. Em 2 de janeiro de 1859, Munby começou a trabalhar no escritório da Comissão Eclesiástica.

${ }^{16}$ STANLEY, L. The Diaries of Hannah Cullwick... Op. cit., p.40. 
Anne McClintock

Nada a usar a não ser os seus grilhões
S/M e poder doméstico

Cullwick e Munby encheram suas vidas com a parafernália teatral do S/M: botas, correntes, cadeados, couro, vendas, correias, roupas, roteiros e fotografias - algumas delas quase pornográficas. Seus jogos incluíam uma variedade de rituais fetichistas: travestismo, acorrentamento, fetichismos de pés e de couro, fetichismo de mãos, rituais de lavagem, infantilismo, bestialismo $e$ voyeurismo. As primeiras transformações em torno das quais giraram seus jogos de fantasia eram as principais transformações do imperialismo industrial: classe (criada em senhora), raça (mulher branca em escrava negra), gênero (mulher em homem), economia (terra em cidade) e idade (adulta em bebê), transformações que derivavam simultaneamente do culto da domesticidade e do culto do império.

Como observa Liz Stanley:

Correntes, lambeção de botas e escurecimento para melhor mostrar o rebaixamento do escravo em relação ao senhor não são apenas imagens de servidão num sentido convencional e por vezes religioso; são também imagens repletas de sobre-tons sadomasoquistas e sexuais. ${ }^{17}$

Mas ela logo rejeita "a utilidade ou propriedade de rotular tal relação de sadomasoquista". ${ }^{18}$ Pois, argumenta, enquanto as pessoas em cenários $\mathrm{S} / \mathrm{M}$ podem mudar de papéis, vemos "que a qualquer momento aquele que é o 'senhor' tem poder, e o que é 'escravo' não tem." Como Cullwick não era nem impotente, nem escravizada nesse sentido "convencional", mas ao contrário "forte, teimosa, independente, segura e competente", o termo

${ }^{17}$ ID., IB., p. 14.

${ }^{18}$ ID., IB., p. 15. 
Couro imperial

sadomasoquismo, diz Stanley, não tem utilidade para entender os jogos de poder de Cullwick e Munby. ${ }^{19}$

Stanley também rejeita o $\mathrm{S} / \mathrm{M}$ como não mais que a imposição retrospectiva de imagens e terminologias do presente sobre o passado. Mas não foi por acaso que a subcultura histórica do S/M surgiu na Europa por volta do fim do século dezoito com a emergência do imperialismo em sua moderna forma industrial. Como indica Foucault, o S/M (que não é simplesmente sinônimo de crueldade e brutalidade) é uma subcultura ritual altamente organizada que "apareceu precisamente ao final do século dezoito" - algumas décadas antes do nascimento de Cullwick e de Munby. ${ }^{20}$ Estudiosos da raça na era vitoriana tardia demonizaram o S/M como a psicopatologia do indivíduo atávico, uma falha do sangue e um estigma da carne. ${ }^{21}$ As "ciências" do homem filosofia, marxismo, antropologia, psicanálise - procuraram conter as irrupções do fetichismo projetando-o numa zona inventada de "degeneração", concebendo-o como uma regressão no tempo histórico para a pré-história da degradação racial, a degeneração da raça inscrita na patologia da alma. O S/M, porém, é menos uma falha biológica, ou uma expressão patológica da natural agressão masculina e da natural passividade feminina, do que uma subcultura organizada e formada em torno do exercício ritual do risco social e da transformação social. Como teatro de conversão, o $\mathrm{S} / \mathrm{M}$ reverte e transforma os significados sociais que toma emprestados.

\footnotetext{
${ }^{19}$ ID., IB., p. 15.

${ }^{20}$ FouCAult, Michel. Madness and Civilization. London, Routledge, 1993 [1961]. Quero enfatizar que por $\mathrm{S} / \mathrm{M}$ refiro-me à subcultura do $\mathrm{S} / \mathrm{M}$ consensual, recíproco, e não a abuso involuntário. Estou também ciente de que esses não são extremos absolutos, mas antes um continuum, e que algumas relações se dão nos limiares da zona do lusco-fusco entre eles.

${ }^{21}$ Para uma análise detalhada do $\mathrm{S} / \mathrm{M}$, ver meu ensaio sobre $\mathrm{S} / \mathrm{M}$ e poder de gênero, Maid to Order: Commercial S/M and Gender Power. In: GiBSON, Pamela Church e GiBSON, Roma. (eds.) Dirty Looks. Londres, British Film Institute, 1993, pp.207-231.
} 
Afirmar que no S/M "quem quer que seja o 'senhor' tem poder e quem quer que seja o escravo não o tem" é tomar o teatro pela realidade; é fazer o mundo andar para a frente. A economia do S/M, no entanto, é a economia da conversão: de senhor em escravo, de adulto em criança, de poder em submissão, de homem em mulher, da dor em prazer, de humano em animal e, de novo, ao contrário. O S/M, como diz Foucault, "constitui uma das maiores conversões da imaginação ocidental: a desrazão transformada em delírios do coração". ${ }^{22} \mathrm{O}$ S/M é o teatro da transformação: ele "faz o mundo andar para trás". ${ }^{23}$

$\mathrm{O} \mathrm{S} / \mathrm{M}$ consensual (a organização coletiva do fetichismo) insiste em exibir o "primitivo" (escravo, criança, mulher) como um personagem no tempo histórico da modernidade. $\mathrm{O} \mathrm{S} / \mathrm{M}$ desempenha o "irracional primitivo" como entrecho dramático; uma performance teatral comunitária no seio da razão ocidental. A parafernália do $\mathrm{S} / \mathrm{M}$ (botas, chicotes, correntes, uniformes) é a parafernália do poder do estado, a punição pública convertida em prazer privado. $\mathrm{O} \mathrm{S} / \mathrm{M}$ faz o poder social andar para trás, encenando visível e ultrajantemente a hierarquia, a diferença $e$ o poder, o irracional, o êxtase ou a alienação do corpo, colocando essas idéias no centro da razão ocidental. O S/M assim revela a lógica imperial do individualismo e o recusa enquanto destino, embora em última análise não se furte ao encanto de seu próprio círculo mágico.

Donde o paradoxo do S/M. De um lado, o S/M exibe uma obediência escravizada às convenções do poder. Em sua reverência ao ritual formal, é a mais cerimonial e decorosa das práticas. $\mathrm{O} \mathrm{S} / \mathrm{M}$ é alto teatro: "belamente adaptado ao simbolismo". ${ }^{24}$ Como teatro, o S/M toma emprestada a decoração,

${ }^{22}$ Foucault, M. Madness and Civilization. Op. cit., p.124.

${ }^{23}$ GoffMAn, Erving. Frame Analysis. New York, Harper and Row, 1974, p.36.

${ }^{24}$ GeBhard, Paul H. Sadomasochism. In: WeineBerg, Thomas e KamEL, G.W. Levi. S and M: Studies in Sadomascohism. Buffalo, Prometheus Books, 1983, p.39. 
Couro imperial

os objetos e vestimentas (algemas, correntes, cordas, vendas) e suas cenas (quartos de dormir, cozinhas, masmorras, conventos, prisões, império) das culturas cotidianas do poder. Ao mesmo tempo, com sua ênfase exagerada nas vestimentas, roteiro e cena, o $\mathrm{S} / \mathrm{M}$ revela que a ordem social não é natural, é roteirizada e inventada.

Para a ciência vitoriana, a natureza era a senhora e a garantia do poder. Assim, para Krafft-Ebing, o S/M encena a agressão sexual "natural" do macho e a passividade sexual "natural" da fêmea: "essa força sádica é desenvolvida pela vergonha e pela modéstia naturais da mulher em relação aos modos agressivos do macho... a vitória final do homem dá a ela uma intensa e refinada satisfação" ${ }^{25} \mathrm{O}$ ultraje do $\mathrm{S} / \mathrm{M}$, porém, é precisamente sua hostilidade à idéia da natureza como guardiã do poder social. Com o máximo de artifício e frivolidade, o $\mathrm{S} / \mathrm{M}$ se recusa a ler o poder como destino ou natureza e inverte de maneira ultrajante os éditos sacramentais do poder $e$ do abandono. Como o S/M é o exercício teatral da contradição social, ele é antinatureza de maneira auto-consciente, não no sentido de que viola o direito natural, mas no sentido em que nega a existência de um direito natural em primeiro lugar. $\mathrm{O} S / \mathrm{M}$ apresenta o poder social como sancionado, não pela natureza, nem pelo destino nem por Deus, mas pelo artifício e pela convenção e, assim, radicalmente aberto à mudança histórica. $\mathrm{O}$ $\mathrm{S} / \mathrm{M}$ zomba da ordem social com sua provocativa confissão de que os éditos do poder são reversíveis. Como tal, é um fenômeno radicalmente histórico.

${ }^{25}$ Krafft-EbInG, Richard von. From Psychopathia sexualis. In: WeInEBERG, T. e KAMEL, G.W. L. S and M... Op. cit., p.27. 
Anne McClintock

\section{O S/M e o culto da domesticidade}

O poder que Cullwick exerceu sobre Munby por toda a vida residia em seu talento teatral para a conversão e sua capacidade de fazer o mundo andar para trás: mudar de criada para senhora, de esposa para escrava, de ama para mãe, de mulher branca para homem negro. Ela era a combinação sonhada, a "abençoada anomalia" que permitiu a Munby encenar em seu próprio teatro privado de transformação os proféticos antigos contrastes de gênero e classe que o deixavam tanto perplexo quanto encantado. Munby registra sua primeira visão dela em seu diário:

Uma jovem camponesa, ela era, uma servente de cozinha... Uma criatura alta e ereta, com passos leves e firmes e porte nobre: seu rosto tinha os traços e expressão de uma dama bem nascida, embora a compleição fosse avermelhada $e$ rústica, \& os olhos azuis inocentes e infantis: seus braços e mãos nuas eram grandes e fortes e rosados até as unhas: mas eram belos... Uma jovem camponesa forte e dada ao trabalho duro, com as marcas do trabalho e da servidão espalhadas nela inteira; mas dotada de uma graça e beleza, uma inteligência óbvia, que seria adequada a uma dama de alta estirpe. Eu sonhara e procurara tal combinação; mas nunca a vi, exceto nela. ${ }^{26}$

Para Munby, Cullwick era o modelo da ambigüidade: uma jovem camponesa que andava pelas ruas da cidade, uma servente na forma de uma dama. Levava as marcas do trabalho, mas com graça aristocrática. Era ao mesmo tempo inocente e ciente do mundo. Era uma criança, mas forte como um homem. Ao fazer o papel tanto da serviçal quanto da dama, da mulher como do homem, Cullwick oferecia a Munby a promessa delirante de incorporar em uma só pessoa a mãe e a enfermeira, a mulher e o

${ }^{26}$ MunBY. Diary, 26 de maio de 1854. Op. cit., p.15. 
Couro imperial

homem, que tanto o excitavam. "Que eu possa", escreveu, "pelo menos aplicar algumas de minhas teorias nessa terna criada: que eu encontre paz e conforto no amor de mãe e em outro tão diferente". ${ }^{27} \mathrm{~A}$ forte atração que Cullwick exercia sobre Munby era seu talento em desempenhar "tão bem cada papel". Ele a lembra sentada depois da labuta de um dia "elegante em seda preta e com a cabeça coberta... pois não é uma criada durante o dia e uma dama à noite? $\mathrm{E}$ desempenha cada um dos papéis tão bem, que às vezes parece incapaz do outro?"28 "Num momento ela é o próprio padrão da faxineira da cozinha, desajeitada e forte, trabalhando entre suor e sujeira". No instante seguinte, ela se transforma "na perfeita imagem da dama elegante e serena [Fig.3.13, 3.14]". ${ }^{29}$

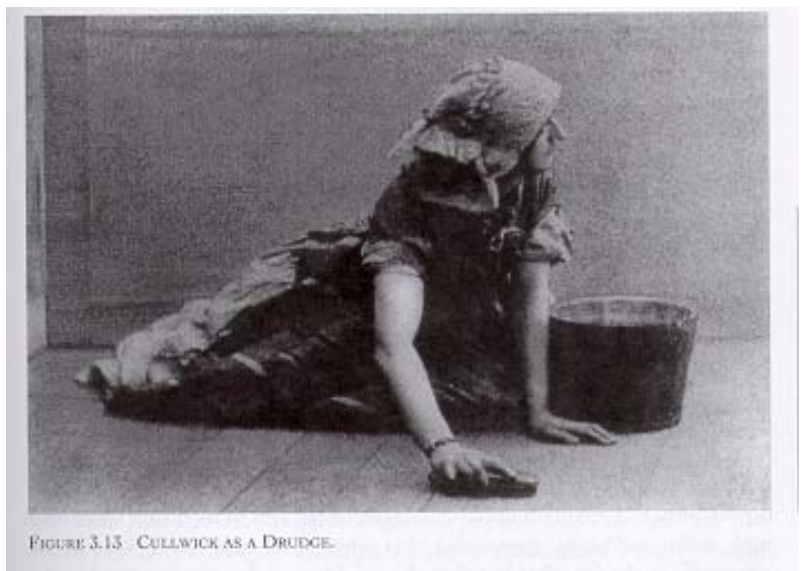

Fig.3.13. Cullwick lavando o chão.

${ }^{27}$ Hudson, D. Munby, man of two worlds... Op. cit., p.70. Robert L. Stevenson, do mesmo modo, assim chamava sua babá: "Minha segunda mãe, minha primeira esposa/ O anjo de minha primeira infância". In: SMITH, Janet Adam. (ed.) Collected poems. London, Rupert-Hart Davis, 1951, p.361.

${ }^{28}$ Hudson, D. Munby, man of two worlds... Op. cit., p.329.

${ }^{29}$ ID., IB., p. 108. 
Cullwick oferecia a Munby a ilusão do controle sobre as contradições que constituíam sua identidade. Ele admirava sua força musculosa e sua "hombridade" que lhe permitiam sentir-se, em contraste, deliciosamente "fêmea", mas de tal modo que não ameaçasse sua precária e compulsória masculinidade. ${ }^{30} \mathrm{E}$, cedendo à fantasia de que era senhor de suas cerimônias, Munby cedia ao que John Berger chamou de "Tentação de Pigmalião" o desejo (infantil) de conformar a vida de outro ser segundo os ditados de nossos desejos. Mas como o "domínio" de Munby sobre Cullwick não era mais do que a dádiva teatral que ela the dava, que ela podia retirar a qualquer momento (e de fato o fez), e como as contradições que o afligiam eram contradições sociais que não poderiam ser resolvidas ao nível pessoal, a cena do fetiche estava destinada a se repetir mais e mais vezes.

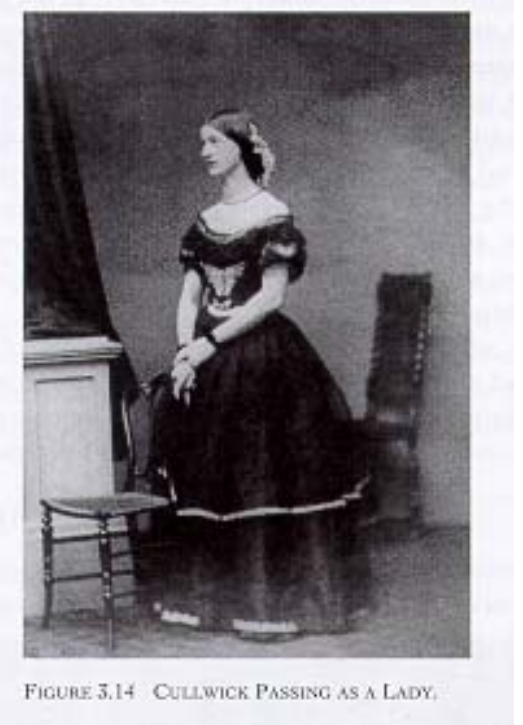

Fig. 3.14. Cullwick como dama.

\footnotetext{
${ }^{30}$ As tentativas de Munby em posar como um homem da classe trabalhadora foram poucas e recebidas com muita hilaridade por parte de Cullwick.
} 
Couro imperial

O S/M é um teatro de signos. Munby não podia evitar seu fascínio pelos signos visíveis e escritos da domesticidade de Cullwick. A representação da domesticidade como alegoria social e imperial o mantinham preso. Obcecado com a escrita, Munby exigia que quando Cullwick não pudesse aparecer fisicamente no "signo" de sua sujeira, lhe mandasse signos verbais na forma de seus diários. E Cullwick, por sua vez, rapidamente aprendeu a usar seu diário e suas apresentações teatrais para manipular os desejos de Munby e manter controle sobre ele.

De fato, não era tanto a realidade do trabalho feminino que cativava Munby, mas a representação do trabalho: o trabalho como espetáculo, como fotografia, como linguagem, como diário, como esboço, como roteiro, como parafernália teatral da domesticidade: vassouras, baldes, sabão, sujeira - fetiches que não podem, em minha opinião, ser reduzidos a uma simples lógica fálica. Em seu teatro de conversão, objetos domésticos mundanos passam a ser investidos de grande poder fetichista, como signos ambivalentes da subordinação doméstica e do poder doméstico. Por que a ênfase nos signos?

Como teatro de signos, o $\mathrm{S} / \mathrm{M}$ oferece controle temporário sobre o risco social. Ao projetar e controlar o enquadramento da representação, em outras palavras, o quadro de controle - o diário, a câmera, a cena teatral - o ator encena a delirante perda de controle numa situação de controle extremo. Para Munby, a perda do controle e a confusão do limite social eram mediadas por uma preocupação excessiva com o controle. Ele dependia profundamente dos quadros de controle, através dos quais manipulava a encenação do risco social. Manipular o quadro de controle - a fotografia, o esquete, o diário, o roteiro, o circo e, em particular, a troca de dinheiro - era indispensável para sua sensação de domínio sobre o que de outra maneira apresentaria ambigüidades terriveis.

O S/M é assombrado pela memória. Ao reinventar a memória do trauma e ao encenar a perda de controle numa situação que em realidade é de excessivo controle, o ator ganha 
poder simbólico sobre a perigosa memória. O S/M permite um triunfo delirante sobre a memória e, a partir desse triunfo, um excesso orgásmico de prazer. Mas como o triunfo sobre a memória é teatral e simbólico, por mais intensamente sentido que seja na carne, a resolução é sempre adiada. Por essa razão, a memória (a cena) retorna para perpétua re-encenação, e a repetição compulsiva surge como princípio fundamental da estruturação do S/M.

Uma tendência do feminismo tem sido demonizar o S/M heterossexual como exercício sancionado da dominação masculina sobre as mulheres. "O sadomasoquismo é o autorebaixamento em todos os níveis que torna as mulheres incapazes de executarem objetivos verdadeiramente feministas". ${ }^{31}$ Mas, com maior freqüência, a cultura S/M revela o oposto: "No mundo do sadomasoquista, não há nada de 'anormal' em um macho que seja passivo ou submisso. De fato, a passividade masculina é de longe o fenômeno mais comum". ${ }^{32}$ Não é então de surpreender que Munby fosse o que é, na fala comum, chamado de "infantilista", adorando, como adorava, ser banhado por Cullwick, erguido em seus braços fortes, embalado e atraído a seu colo farto como um bebe. ${ }^{33}$ Talvez nesses encontros Munby conseguisse se render em delírio à memória de seu desamparo nos braços da primeira ama, ao prazer voyeurista do espetáculo de uma

\footnotetext{
${ }^{31}$ In: LinDEN, Robin Ruth et alii. (eds.) Against Sadomasochism: a Radical Feminist Analysis. San Francisco, Frog in the well, 1982, p.28.

${ }^{32}$ Homens "subordinados" freqüentemente têm um papel em enredos feitos a partir da "degradação" da domesticidade feminina: varrer compulsivamente, limpar, lavar, sob o impacto de insultos e calúnias verbais. Algumas dominadoras têm seus "bichinhos de estimação" que comumente fazem seu serviço doméstico. Ver MCCLinTOCK, A. Maid to Order... Op. cit., pp.207-231.

${ }^{33} \mathrm{O}$ fetichismo infantil de Munby é comum no $\mathrm{S} / \mathrm{M}$ : "Há toda uma área de comportamento desviante, chamada de "bebezismo", na qual o cliente gosta de vestir um pijama, sugar uma boneca gigante ou um de seus seios e ser embalado." TAYLOR, Allegra. Prostitution: what's love got to do with it?. London, Optima, 1991, p.39.
} 
Couro imperial

trabalhadora a cuidar de seu corpo passivo e ao reconhecimento proibido do poder social da mulher da classe trabalhadora.

A contradição de Munby era depender de mulheres da classe trabalhadora que a sociedade estigmatizava como subservientes. Ao reconhecer ritualmente Cullwick (como fez com sua babá) como socialmente poderosa, ele podia reconhecer sua identificação infantil proibida com mulheres poderosas, particularmente as da classe trabalhadora. Seu fetiche de lavar os pés era um ritual de expiação que simbolicamente o absolvia da culpa e da "sujeira", simultaneamente permitindo-lhe ao mesmo tempo ceder ao espetáculo voyeurístico e proibido do trabalho e do poder das mulheres. De qualquer forma, o reconhecimento do trabalho doméstico como valioso era socialmente tabu e tinha que ser mediado e controlado por roteiros cuidadosamente arranjados.

Em certa ocasião, por exemplo, Cullwick convidou Munby a visitá-la em seu local de trabalho. Uma vez lá, ele mergulhou num estado de agitação e aflição extrema. "Vê-la em pé numa sala íntima em suas roupas de criada e saber que ela é uma criada, $e$ que o piano, os livros, os quadros pertenciam à sua patroa... isso eu não pude suportar". ${ }^{34}$ Ver Cullwick em seu local de trabalho forçou Munby a reconhecer que em realidade ele não controlava a vida dela, e muito menos era seu dono. Em outra ocasião, ele se surpreendeu ao visitá-la no trabalho e ver quão verdadeiramente imunda e exausta ela estava. O que o aborreceu nas duas ocasiões foi o colapso de seu quadro de controle e assim a perda de sua ilusão de domínio da cena. Ver Cullwick no trabalho era uma lembrança forçada de que uma outra mulher pagava o salário dela e lhe dava ordens. Da mesma forma que se sentiu ultrajado ao ver um jornalista fotografando "suas" miniaturas de mulheres, a visão de Cullwick no trabalho roubou a Munby sua ilusão de que controlava o perigoso cenário, e violentamente o precipitou numa crise.

${ }^{34}$ Hudson, D. Munby, man of two worlds... Op. cit., p.116. 
A troca de papéis é uma característica comum do S/M e em suas reuniões secretas de espetáculo, Cullwick e Munby freqüentemente trocavam de papéis. A maior parte do $\mathrm{S} / \mathrm{M}$ é menos "desejo de infligir dor", como disse Freud, do que a organização teatral do risco social. ${ }^{35}$ Contra as percepções populares, grande parte do $\mathrm{S} / \mathrm{M}$ não envolve qualquer dor. Suas violações rituais são menos violações da carne do que encenações simbólicas de memórias de violações do eu, violações que podem assumir miríades de formas. Como dizem Weinberg e Kamel, "cenários de S/M são produzidos voluntária e cooperativamente; e o mais freqüente é a encenação das fantasias do(a) masoquista". ${ }^{36}$ Muitos fetichistas S/M dizem que de fato é o "de baixo" que detém o controle.

Havelock Ellis observa que boa parte do S/M é motivado por amor. Longe de ser um exercício tirânico de uma vontade sobre outra, o S/M é tipicamente colaboração, envolvendo cuidadosos rituais de iniciação, uma escrupulosa definição de limites e uma constante confirmação de reciprocidade que pode vincular os participantes num êxtase de interdependência: abandono no momento mesmo da dependência. Mas como o S/M envolve a negociação de fronteiras perigosas, qualquer violação do roteiro está eivada de riscos, enquanto que a fidelidade mútua à combinação cria uma intimidade de tipo muito intenso. Se o controle se perde em qualquer ponto, ou há transgressão das regras do jogo, qualquer dos parceiros pode entrar em pânico. Donde a importância e prevalência do roteiro no S/M consensual.

\footnotetext{
${ }^{35}$ FreUd, S. Three essays on the theory of sexuality. N.Y., Basic Books, 1962, p.23.

${ }^{36}$ Weineberg, T. e KAmel, G.W. L. $S$ and M... Op. cit., p.20.
} 
Couro imperial

\section{A pulseira de escrava Recusa da abjeção}

Durante anos, Cullwick usou uma "pulseira de escrava" de couro imundo e uma corrente com cadeado em volta do pescoço. Sua razão original para a pulseira, diz ela, era apoiar o pulso depois de um deslocamento. ${ }^{37}$ Mais tarde passou a usá-la como "signo" de seu amor e servidão a Munby. Uma vez em que insistiu em usar a pulseira ao servir o jantar, permitindo que fosse vista em seu pulso pelos convidados, a patroa ordenou-lhe que a tirasse. Cullvick recusou-se a obedecer e foi demitida na mesma hora, preferindo, como orgulhosamente registra em seu diário, perder o emprego a tirar "o signo de que sou uma serviçal \& pertenço ao Massa". ${ }^{38} \mathrm{O}$ que fazer da pulseira de escrava de Cullwick, já que ela faz parte da zona do fetiche?

$\mathrm{O}$ fetiche incorpora uma crise do significado social. $\mathrm{Na}$ pulseira de escrava de Cullwick convergem três das contradições formadoras da era vitoriana: entre trabalho escravo e trabalho assalariado; entre o domínio privado da domesticidade e o domínio público do mercado; e entre a metrópole e o império. No fetiche da pulseira de escrava, raça, classe e gênero de sobrepõem e mutuamente se contradizem; a pulseira de escrava, como a maioria dos fetiches, é sobredeterminada.

A transgressão de Cullwick foi usar num jantar (teatro do consumo da classe média e do lazer feminino) o signo proibido do trabalho das mulheres. Cullwick pôs escandalosamente em crise a relação incomensurável entre a doutrina vitoriana de que as mulheres não deviam trabalhar em busca de lucro e o signo visível do trabalho doméstico feminino: o tênue e ilícito cheiro da cozinha, a mancha da água suja, a marca do trabalho no couro imperial. Cullwick ofendeu a convenção exibindo, por sua própria

${ }^{37}$ Stanley, L. The Diaries of Hannah Cullwick... Op. cit., p.307.
${ }^{38}$ Hudson, D. Munby, Man of Two Worlds... Op. cit., p.184. 
vontade teimosa, a evidência pública da sujeira doméstica das mulheres, banida por decreto vitoriano para cozinha e fundos, celeiro e sótão - a arquitetura do não visto. Ao recusar tirar a pulseira, Cullwick estava recusando a abjeção social de seu trabalho e sujeira doméstica [Fig. 3.15].

Para Cullwick, o fetiche da pulseira de escrava especificava o reconhecimento do valor social. A idéia do trabalho oculto é fundamental para a análise marxista do fetiche da mercadoria. A idéia da fixação traumática numa experiência intensa é fundamental para a noção psicanalítica do fetiche sexual. As duas idéias se fundem na pulseira de escrava. Numa observação importante, William Pietz nota que o fetichismo surge muitas vezes a partir de uma crise que "reúne e fixa em intensidade singularmente ressonante e unificada um evento irrepetível (permanente na memória), um objeto particular e um espaço localizado". Paradoxalmente, esse momento de crise, por sua "degradação em relação a qualquer código reconhecível de valor", se torna "um momento de valor infinito". ${ }^{39}$ A morte da mãe de Cullwick foi precisamente um momento irrepetível; o espaço localizado foi o espaço arquitetônico da domesticidade de classe alta; $e$ o objeto particular foi o fetiche imperial da pulseira de escrava. Aqui a crise envolve o corpo da mãe, mas não da maneira que Freud previu.

${ }^{39}$ PIETZ, William. The Problem of the Fetish, II. Res 13, Spring, 1987, p.34. 
Couro imperial

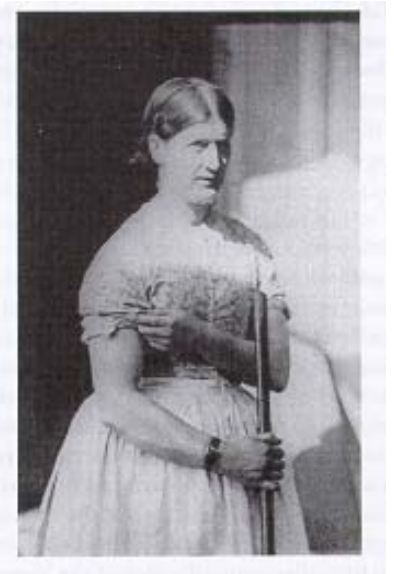

Ficume 3.15 Derism Dispur.

Fig.3.15. Exibição desafiadora.

Aos quatorze anos, trabalhando fora de casa como babá, Cullwick foi chamada sem qualquer aviso e informada sem rodeios de que seus pais tinham morrido de doença algumas semanas antes. Deixada a chorar sozinha no chão aonde caíra $e$ vendo recusada a licença para voltar para casa e ajudar seus irmãos e irmãs órfãos, Cullwick sentiu que a morte de sua amada mãe tirava todo valor de sua vida: "Parecia que minha dedicação à vida e ao trabalho tinham sumido". A crise assumiu a forma de fetiche, pois a violência do encontro fortuito com a morte $e$ a recusa dos patrões ao seu luto marcaram uma ruptura radical com a história e com a comunidade, custando-lhe não só a família, mas também o valor simbólico do trabalho e seu senso de controle sobre a própria vida. A morte da mãe a atirou a uma intensa colisão com o poder da família de classe alta de subjugar seu valor às necessidades dela. "Não acredito que [superarei isso]. Nunca mais brincarei ou jogarei bola no jardim" ${ }^{40}$ Daí em diante, sua mãe será representada pelo esforço da memória: "tento sonhar com seu fantasma".

${ }^{40}$ StAnLEy, L. The Diaries of Hannah Cullwick... Op. cit., p.37. 
Com a pulseira de escrava, Cullwick fez da memória um objeto repetível. Em todas suas fotografias ela posa de tal maneira a exibir a pulseira de escrava ao máximo efeito. Como todos os fetiches, a pulseira de escrava era contraditória, incorporando o poder da classe alta de escravizá-la, ao mesmo tempo que exibia sua determinação de reivindicar o valor de seu trabalho e da memória de sua mãe. No "lugar marcado" de seu pulso, ferido pelo trauma do trabalho, ela transformou a servidão num sinal secreto de auto-afirmação. Exibindo deliberadamente a pulseira num jantar ela reafirmava sua independência e seu direito a contratar trabalho como lhe aprouvesse. Dispensando o emprego, afirmou seu direito de controlar o próprio corpo e seu próprio trabalho. Ligando-se a Munby como sua "escrava" simbólica, assumiu o controle, no domínio simbólico, da falta de controle no domínio social. Sua recusa inflexível e inteiramente independente de retirar a pulseira revelava, além disso, que ela a valorizava apenas como símbolo do poder sobre o qual tinha controle em última análise. Mais importante, exibindo seu pulso sujo de trabalho, rejeitava o estigma da vergonha ligado ao trabalho doméstico. ${ }^{41}$ Se o culto vitoriano da domesticidade destituía seu trabalho de reconhecimento social, ela teimosamente exibia as mãos em público para mostrar seu valor econômico: "minhas mãos e meus braços são meu chefes, com que ganho minha vida". ${ }^{42}$

A ligação fetichista de Cullwick com sua pulseira de escrava expressava, sugiro, uma tentativa de reinventar a memória do valor de sua mãe aos olhos da classe alta. A subestimação de seu trabalho pela classe alta encontrava sua antítese em sua própria superestimação do mesmo. Sua pulseira de escrava e sua profunda dedicação ao trabalho doméstico incorporavam uma

\footnotetext{
${ }^{41}$ Como Cullwick anota, "Nunca encontrei uma criada que não tivesse vergonha do trabalho sujo." ID., IB., p.96.

${ }^{42}$ ID., IB., p. 76.
} 


\section{Couro imperial}

determinação compulsiva de manter sob controle, a qualquer custo físico, o âmbito do trabalho ao qual estava subordinada.

As experiências inter-culturais marcadas pelo fetiche se fundem na pulseira de escrava: nas relações triangulares entre escravidão como base do capitalismo mercantil; no trabalho assalariado como base do capitalismo industrial; e no trabalho doméstico, como base do patriarcado. Usando de maneira flagrante em seu corpo o couro fetiche do trabalho forçado Cullwick punha em questão a separação liberal entre público e privado, insistindo em exibir seu trabalho, sua sujeira, seu valor no lar: esse espaço supostamente além do trabalho escravo e do trabalho assalariado. Ao exibir sua sujeira como valor, ela desmentia a desaprovação do trabalho das mulheres e o controle racional da classe média sobre a sujeira e a desordem.

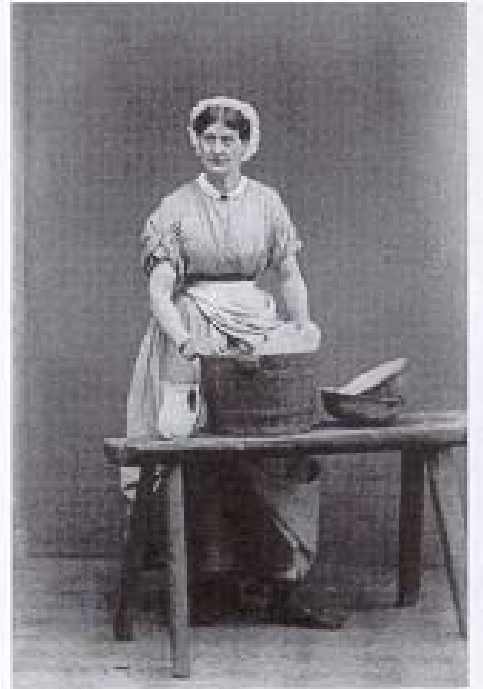

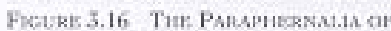
Donestue Fetrans.

Fig.3.16. A parafernália do fetichismo doméstico

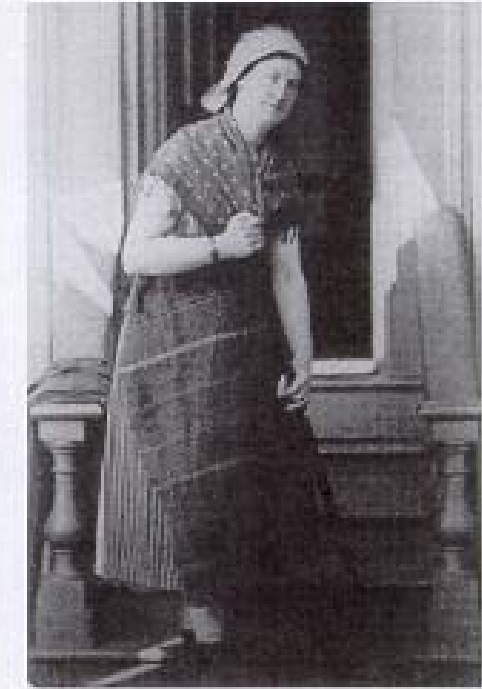

Figure 3.17 The Duxt FEush.

Fig. 3.17. O fetiche da sujeira. 
Anne McClintock

\section{O fetiche da sujeira}

A principal objeção dos empregadores de Cullwick à pulseira era sua sujeira. Os rituais de Cullwick e Munby - a limpeza dos pés e das botas, os rituais de lavagem, o desejo voyeurístico de Munby de ver Cullwick em "sua sujeira", o "enegrecimento" deliberado de Cullwick, as fotografias, a pulseira - eram organizados de maneira complexa, mas repetitiva em torno do fetiche vitoriano da sujeira [Figs.3.16-3.18]. Por que a sujeira exercia tal fascínio compulsivo sobre suas imaginações, assim como sobre a era vitoriana como um todo?

Nada é inerentemente sujo: a sujeira exprime uma relação ao valor social e à desordem social. A sujeira, como sugere Mary Douglas, é o que transgride a barreira social. ${ }^{43}$ Uma vassoura no armário da cozinha não é suja, mas o é se estiver sobre a cama. O sexo com o cônjuge não é sujo, mas convencionalmente o mesmo ato com uma prostituta o é. Na cultura vitoriana, a iconografia da sujeira tornou-se profundamente integrada no policiamento e na transgressão das barreiras sociais.

A sujeira é o que sobra depois que o valor de troca foi extraído. Na cultura vitoriana, a relação corporal com a sujeira exprimia uma relação social com o trabalho. A classe média masculina - procurando desmantelar o corpo aristocrático e o regime aristocrático de legitimidade - passou a distinguir-se como classe de duas maneiras: ganhava sua vida (ao contrário da aristocracia) e tinha propriedade (ao contrário da classe operária). Diferentemente da classe operária, porém, seus membros, especialmente seus membros femininos, não podiam carregar em seus corpos a evidência visível do trabalho manual. A sujeira era um escândalo vitoriano porque era a evidência excedente do

${ }^{43}$ Douglas, Mary. Purity and Danger. London, Routledge and Kegan Paul, 1966. Ver também DAVIDOFF, L. The Rationalization of Housework. In: LEONARD, Diana e Allen, Sheila, (eds.) Sexual Divisions Revisited. Basingstoke, MacMillan, 1991, p.63. 
Couro imperial

trabalho manual, o resíduo visível que teimosamente permanecia depois que o processo da racionalidade industrial tinha feito sua parte. A sujeira é a contraparte da mercadoria; algo é sujo precisamente porque destituído de valor comercial, ou porque transgride o mercado comercial "normal". A sujeira é por definição inútil, porque é aquilo que fica fora do mercado.

Se, como observou Marx, o fetichismo da mercadoria exibe com ostentação a superestimação da troca comercial como princípio fundamental da comunidade social, então a obsessão vitoriana com a sujeira configura uma dialética: a subestimação fetichizada do trabalho humano. Espalhada nas calças, nos rostos, nas mãos e aventais, a sujeira era o traço marcante da classe trabalhadora e do trabalho feminino, evidência indecorosa de que a produção fundamental da riqueza industrial $e$ imperial estava nas mãos e nos corpos da classe trabalhadora, das mulheres e dos colonos. A sujeira, como todos os fetiches, assim expressa uma crise de valores, pois contradiz o ditado liberal de que a riqueza social é criada pelos princípios racionais abstratos do mercado $e$ não pelo trabalho. Por essa razão, a sujeira vitoriana entrara no domínio simbólico do fetichismo com grande força.

À medida que o século dezenove avançava, a iconografia da sujeira tornou-se uma poética de vigilância, exibindo para a polícia os limites entre a sexualidade "normal" e a "suja", entre o trabalho "normal" e o "sujo", entre o dinheiro "normal" e o "sujo". O sexo sujo - masturbação, prostituição, sexualidade lésbica e gay, as hostes das "perversões" vitorianas - transgredia a economia libidinal da reprodução heterossexual controlada pelos homens dentro de relações sexuais conjugais (sexo limpo que tem valor). De maneira semelhante, o dinheiro "sujo" - associado com prostitutas, judeus, jogadores, ladrões - transgredia a economia fiscal do mercado de trocas controlado pelos homens (dinheiro limpo que tem valor). Como as prostitutas $e$ as mineiras, as criadas domésticas ficavam no perigoso limiar do trabalho normal, do dinheiro normal e da sexualidade normal, e vieram a 
ser representadas na iconografia da "poluição", "desordem", "pragas", "contágio moral" e "degeneração" racial.

Aqui surge um aspecto crucial do imperialismo vitoriano. A relação entre a economia "normal" do casamento heterossexual $e$ a economia "normal" da troca capitalista era legitimada e tornada natural por referência a um terceiro termo: a invenção da zona "anormal" do primitivo e do irracional. O dinheiro, o trabalho e a sexualidade eram vistos como relacionados entre si pela analogia negativa com o domínio da diferença racial e do império. Assim, contradições históricas internas ao liberalismo imperial (as distinções entre público e privado; trabalho pago e trabalho não pago; a formação do proprietário masculino individual $e$ a negação de que escravos, mulheres e os colonizados fossem "indivíduos capazes de posse"; entre o racional e o irracional) eram contidas pelo deslocamento a um terceiro termo: o termo raça. Distinções de classe e de gênero foram deslocadas $e$ representadas como diferenças raciais naturais no tempo e no espaço: a diferença entre o presente "iluminado" e o passado "primitivo".

A pulseira de escrava de Cullwick incorpora traços tanto da memória pessoal como da histórica: seu próprio trabalho subjugado $e$ o trabalho escravo sobre o qual o capital industrial se assentava. Na segunda metade do século dezessete, os negros trazidos para a Grã Bretanha pelos traficantes, mercadores e donos de fazendas viviam espalhados pela Inglaterra, mas se concentravam principalmente em Londres. No início do século dezoito, Londres e Bristol eram movimentados portos de escravos, e continuaram ainda por cem anos a amealhar enormes lucros do transporte criminoso e da venda de seres humanos. Na Grã Bretanha, a posse de um escravo negro se tornou emblema da nova riqueza imperial e anúncios com gritos e alaridos à procura de escravos fugidos mostram que eles eram

habitualmente obrigados a usar coleiras de metal rebitadas ao redor de seus pescoços. Feitos de bronze, cobre ou 
Couro imperial

prata, os colares eram em geral inscritos com o nome do dono, suas iniciais, armas ou outros símbolos. ${ }^{44}$

No cortejo do Lorde Prefeito, festival anual dos capitalistas mercantis de Londres, os negros eram obrigados a vestir roupagens opulentas e esses colares fetiche, exibindo em demonstrações públicas de excesso suntuário a riqueza da metrópole imperial e o trabalho forçado sobre o qual se erguia o capitalismo mercantil.

Aqui, o colar de escravo incorpora uma contradição entre a exibição extravagante de escravos negros por seu valor $e$ a negação total do valor de suas vidas e trabalho. O colar de escrava de Cullwick, como fetiche, incorporava assim uma dupla negação: o repúdio histórico tanto do trabalho escravo quanto do trabalho das mulheres de classe trabalhadora enquanto fundamento do poder industrial moderno. A pulseira de escravo $e$ o colar de correntes traziam para o lar burguês a memória do império - correntes, cinturões e escravidão - no momento preciso em que a economia industrial se transformava de um mercado de escravos num mercado de salários. A pulseira de escrava fetiche encena assim a história do capital industrial assombrada pela traumática e inarredável memória da escravidão imperial.

\section{$\mathrm{S} / \mathrm{M}$ e rituais de reconhecimento}

O S/M representa o fracasso da idéia iluminista da autonomia individual, encenando teatralmente a dinâmica da interdependência na busca do prazer pessoal. Mas o S/M não é meramente um drama existencial hegeliano atemporal entre o Eu e o Outro, o Ser e o Nada. Ele é, ao contrário, uma sub-cultura

${ }^{44}$ FrYER, Peter. Staying Power: the History of Black People in Britain. London, Pluto Press, 1984. Os signos comerciais das tabacarias e das pensões freqüentemente mostravam negros como signos fetiches do comércio com seres humanos. Escravos negros de famílias com títulos [de nobreza] eram usualmente exibidos com vestes vistosas, jóias, rendas e roupas enfeitadas. 
histórica que retira sua lógica simbólica das contradições sociais em mudança. Qual é a lógica social do prazer de Cullwick no S/M doméstico? "O desejo de submissão", escreve Kamel, "representa uma transposição peculiar do desejo de reconhecimento". ${ }^{45} \mathrm{Se}$ Cullwick deu licença a Munby para negociar as contradições de classe e gênero, Munby deu a Cullwick o ritual de reconhecimento do valor de seu trabalho que ela sempre desejou.

Quando menina, a identidade de Cullwick surgiu através de um paradoxo. Por uma obscura economia de afirmação social por auto-negação e os éditos de rebaixamento de classe, ela aprendeu muito cedo que só seria recompensada se negasse a si mesma. ${ }^{46}$ Desempenhando rituais de obediência institucionais $e$ sancionados, cortejando e curvando-se diante dos bem nascidos, obteve afirmação através de sua auto-negação. A necessidade de reconhecimento pela classe alta entrou em sua identidade com a força de uma contradição inarredável. ${ }^{47}$ Cullwick herdou um perigoso paradoxo. Sua primeira fonte de auto-estima era o reconhecimento como trabalhadora. Isso significava ser obediente, resistente, independente e capaz de economia - mas, por decreto vitoriano, apenas se permanecesse invisível. O trabalho doméstico configurava da maneira mais profunda sua auto-estima $e$ as fronteiras entre ela mesma $e$ os outros - as mulheres em

${ }^{45}$ WeInEBERG, T. e KAMEL, G.W. L. S and M... Op. cit., p.56.

46 "Comecei a trabalhar muito cedo - antes de realmente entender o significado disso - e na escola da Assistência Social, aprendi a fazer as mesuras para as senhoras e cavalheiros e me parecia inteiramente natural pensar neles como absolutamente acima das classes baixas e que era nosso lugar cumprimentar e ficar ao seu dispor." STANLEY, L. The Diaries of Hannah Cullwick... Op. cit., p.35.

${ }^{47}$ Quando ela trabalhava fora de casa, algumas de suas primeiras lições sobre identidade eram lições de afirmação via grandes feitos de trabalho: "Ela (Mrs Phillips) sempre me elogia depois de eu ter limpado o chão de tijolos vermelhos com minhas mãos \& de joelhos \& escovado as enormes mesas brancas na cozinha. Eu podia limpar a sala de jantar \& o longo hall de entrada \& os degraus da porta \& tudo isso antes do café da manhã.” ID., IB., p.74. 
Couro imperial

particular. ${ }^{48} \mathrm{E}$, no entanto, os feitos extraordinários de seu trabalho doméstico eram pública e ritualmente desprezados como trabalho sujo, trabalho sem valor social. Sua querida mãe trabalhadora - a primeira a atribuir reconhecimento e limites a seu eu - era socialmente desprezada como servil e inferior, digna de vergonha. Cullwick sabia muito bem o quanto as mulheres de classe alta dependiam de seu trabalho:

A srta. M... estava exigente e quase guinchando, \& no entanto tão pequenina e frágil. Parecia difícil ser assim provocada por ela, \& ser paciente \& dócil com alguém que eu quase poderia esmagar com uma mão \& eu tão mais alta que ela... \& eu também tinha pena dela. ${ }^{49}$

E no entanto essas mulheres desamparadas negavam-lhe constantemente o mágico ingrediente do reconhecimento social.

Cullwick gastava muito de sua energia no que poderia ser chamado de rituais de reconhecimento para a classe alta. Curvando-se e fazendo mesuras, tomando afetadamente o chapéu de um homem, baixando teatralmente os olhos e a voz, deixando a sala de costas, ajoelhando-se para tirar os sapatos de seu senhor, deixando-se pisar pelas mulheres de classe alta - todas eram performances rituais em que Cullwick reconhecia formalmente aqueles que lhe pagavam para que o fizesse. Sua presença ritualizada era assim um elemento necessário na identidade de classe de seus empregadores; e no entanto, em contraste, o reconhecimento social de sua força era sempre adiado. "De certa forma eu nunca fui muito elogiada no serviço",

\footnotetext{
${ }^{48}$ Seu motivo para trabalhar tinha sido, em primeiro lugar, agradar a sua mãe. Cullwick adorava sua mãe e vivia para ela, se auto-sacrificando e trabalhando duro para agradá-la: "Estava pensando como vou trabalhar \& fazê-la feliz, pois ela terá todo meu dinheiro." ID., IB., p.82. O dinheiro que ela ganhou com trabalho duro conquistou o amor de sua mãe e a compensou da angústia da separação. Dinheiro era o signo oculto do reconhecimento da classe alta; ao voltar para casa, ela trocou este símbolo pela aprovação aberta de sua mãe.

${ }^{49}$ ID., IB., p. 89.
} 
observa com tristeza. ${ }^{50}$ Pode-se chamar ao projeto que animava sua vida de projeto de reconhecimento, no exato momento em que o trabalho manual feminino era afastado da vista.

Cullwick insiste repetidamente em que gosta do trabalho $e$ gosta de ser da classe trabalhadora: "para a liberdade e a verdadeira humildade não há nada como ser uma empregada de todo serviço". ${ }^{51}$ Seu diário contém inúmeras passagens como as seguintes: "O verão avançava e eu trabalhava e gostava disso". ${ }^{52}$ "Eu gosto da vida que levo - trabalhando aqui \& encontrando M. no domingo, quando posso". ${ }^{53}$ Também prefere o trabalho físico, que onera sua enorme força e lhe dá um sentido de realização: "Freqüentemente limpava as escadas dela \& sacudia os tapetes no pátio \& realmente gosto mais disso do que de fazer o rol". O trabalho, especialmente o trabalho visível, era uma exibição de força e sua capacidade de realizar coisas impressionantes a enche de prazer. Ela tem orgulho desmedido de sua destreza muscular $e$ gosta de levantar Munby e outros homens para exibir sua força: "eu posso erguer meu senhor \& carregá-lo quase como se fosse uma criança". ${ }^{4}$ "Eu o levantei com facilidade \& o carreguei \& e então ele me levantou \& disse que eu era pesada - eu peso quase setenta quilos". ${ }^{55}$ Media seu corpo habitualmente para provar seu valor - uma imitação irônica do discurso vitoriano da degeneração

50 "Gosto de estar sozinha em minha cozinha e no meu trabalho." ID., IB., pp.453-44. "Porque não me parece certo ter uma criada, já que quero lavar \& fazer o trabalho pesado eu mesma." ID., IB., pp.49, 74.

${ }^{51}$ ID., IB., p.143. Seus diários mostram claramente que ela trabalhava para satisfazer sua necessidade de valor interior. Quando a empregada da senhora lhe perguntou "Hannah, porque você trabalha tanto?", ela respondeu: "Eu disse que o fazia de fato por gosto." p.47.

52 ID., IB., p.48.

${ }^{53}$ ID., IB., p. 170.

${ }^{54}$ ID., IB., p. 167.

${ }^{55}$ ID., IB., p.124. Uma noite, voltando para casa, ela é abordada por três cavalheiros bêbados que a insultam e tentam se aproveitar dela, mas ela os repele e ameaça atacá-los por sua vez. 
Couro imperial

e do fetiche da mensuração. "Meu braço tem 13 polegadas e 3/4 de circunferência no músculo, [escreve orgulhosa] \& minha mão 4 polegadas e meia de largura" ${ }^{56} \mathrm{Em}$ mais de uma ocasião, porém, a imensa carga de trabalho chegava a ser demais, mesmo para ela: "Levantei \& cheguei na cozinha miserável \& fiquei doente de ver tanta sujeira e trabalho pesado". ${ }^{57}$

Cullwick era levada à indignação impotente quando suas patroas se recusavam a reconhecer seus feitos amazônidas:

Fiz tudo o que podia para mostrar que gosto de trabalho sujo e pesado, mas Mrs. Bishop nunca ficava satisfeita \& eu também não. ${ }^{58}$ Quando Miss Margaret deu suas ordens, começou pelo trabalho \& se disse surpreendida de que tudo não tivesse sido feito melhor. Eu disse, "Bem, senhora, saiba a senhora ou não, trabalhei muito duro... uma quinzena é o mesmo que nada para limpar uma casa grande como esta... Nunca trabalhei tão duro e nunca farei tanto para ninguém mais"... Ela não disse mais nada, mas me deixou doente de desapontamento. ${ }^{59}$

Para Cullwick, o reconhecimento de classe parece importar mais que o de gênero, pondo em questão algumas teorias feministas de que só os homens são os donos do olhar. Com exceção de Munby, ela raramente menciona seus patrões. Nas raras ocasiões em que mulheres de classe alta reconheciam sua força, ela irradia um orgulho especial:

Ela disse, "que braços você tem!" E eu disse, "é sim, senhora, eu sou muito forte \& me fez bem buscar a cerveja no vento estimulante... Voltei com a minha cerveja e me

\footnotetext{
${ }^{56}$ ID., IB., p.127.

${ }^{57}$ ID., IB., p.171.

${ }^{58}$ ID., IB., p.171.

${ }^{59}$ ID., IB., p. 173.
} 
senti bem sendo notada... E meus braços pareciam grandes e vermelhos \& reconheço que pesava uns 70 quilos" ${ }^{60}$

O poder que decorre de ser o espetáculo para o olhar do outro é um poder ambíguo. Permite que se internalize o olhar do voyeur e participe do gozo vicário de seu poder. Mas também alimenta uma dependência correspondente daquele que é dotado do privilégio social da aprovação. As feministas fizeram análises refinadas da prerrogativa masculina do olhar, e no entanto há evidência de que as mulheres de classe alta tinham esse privilégio na vida de Cullwick. Ela se lembra de ter limpado a lareira enquanto as senhoritas Knights obervavam de maneira voyeurista: "A que estava na cama me chamou, \& derramou água na minha mão preta para passar na lareira, \& assim ficou satisfeita". A água na mão realizou uma limpeza batismal e a exclusão do rebaixamento de classe ("ela ficou satisfeita"), dando a Cullwick um de seus sonhados momentos de reconhecimento: "A senhorita Julia gostava de me ver limpar \& depois varrer. Dizia que achava muito interessante ver-me limpar a pintura de modo tão completo". ${ }^{61}$ Seu anelo pelo reconhecimento de classe é mitigado. Ao mesmo tempo, registrar tais momentos no diário renova seu poder sobre Munby.

No teatro privado do S/M doméstico, Munby concedia a Cullwick, repetida e ritualmente, o raro e sonhado reconhecimento de seu trabalho: "pois ele estava e está interessado em meu trabalho" ${ }^{62}$ Munby figurava como testemunha oficial de seu valor doméstico oculto: "Eu escrevia contando tudo a ele". ${ }^{63}$ Nesses momentos, porém, transpira uma curiosa metamorfose. Ao ler o diário mais tarde, Munby é colocado num papel estranhamente feminino, ocupando o mesmo lugar de voyeur do espetáculo

\footnotetext{
${ }^{60}$ ID., IB., p.64.

${ }^{61}$ ID., IB., p.46.

${ }^{62}$ ID., IB., p. 79.

${ }^{63}$ ID., IB., p.179.
} 
Couro imperial

proibido do trabalho de Cullwick ocupado por suas patroas, precisamente aquela associação feminina que tanto o inflamava e encantava. Em seus rituais fetichistas com Munby, Cullwick repetia a cena, mas convertia os termos. Ao pretejar ostensivamente o rosto, ao esfregar graxa nas mãos, deixando-se fotografar "em sua sujeira", Cullwick convertia a cena do repúdio na cena da exibição teatral.

\section{Ambigüidades da dependência}

Não é possível exagerar a influência do Cristianismo sobre a vida fetiche de Cullwick. O Cristianismo oferecia a Cullwick a esperança do reconhecimento posterior: Deus via seu trabalho, Deus reconhecia seu valor. Rebaixando-se na lida, exaltava a si mesma aos olhos do Senhor. Trabalhando, acumulava capital espiritual, guardando um estoque de valor excedente no céu. A economia do Cristianismo é a economia da conversão: os de baixo exaltados, os de cima rebaixados. ${ }^{64}$ Como o Cristianismo, o $\mathrm{S} / \mathrm{M}$ realiza o paradoxo do sofrimento redentor e, como o Cristianismo, toma forma em torno da lógica masoquista da transcendência através da mortificação da carne. Pelo autorebaixamento, o espírito se liberta num êxtase de abandono. $\mathrm{O}$ $\mathrm{S} / \mathrm{M}$ compartilha com o Cristianismo uma iconografia teatral da punição e da expiação: rituais de lavagem, agrilhoamento, flagelação, ferimentos no corpo e tortura simbólica. Tanto no S/M como no Cristianismo o desejo terreno obtém estrito pagamento numa economia de sofrimento e prazer.

Os rituais de lavagem do casal, sugiro, permitiam a Munby exercitar seu fetichismo das mãos - observando as mãos enegrecidas, "masculinas", tocarem, esfregarem e massagearem suas extremidades masculinas. Eram rituais de purificação, um perdão da culpa e da transgressão. Esses rituais de lavagem eram

${ }^{64}$ Culwick praticava a humildade menos porque significasse submissão do que porque significava força. "Ouvi o senhor Bellow dizer uma vez num sermão", escreve ela, "que humildade era força." ID., IB., p.66. 
encenados por Cullwick como uma apropriação da pompa cristã, $e$ lhe ofereciam um adiantamento delirante de seu crédito espiritual - um sabor roubado do que seria sua exaltação no além. Para ambos, esses rituais fetichistas exprimem uma troca de prazer por poder muito mais complexa do que revelam as oposições fáceis entre vítima e opressor.

Para Cullwick, suas exibições teatrais de submissão eram um modo de negociar poder sobre Munby, e também um meio de obter controle sobre sua própria impotência social. Ela via claramente sua "escravização" como mais cerimonial que real um oferecimento simbólico feito a Munby do qual podia se retirar a qualquer momento. Seus diários mostram-na determinada a ser senhora de seu teatro de submissão, e reagia com fúria espantosa quando Munby tinha a temeridade de sugerir que ela realmente era sua escrava ou a tratava como se realmente fosse uma serviçal. Cullwick defendia com ferocidade seu direito de controlar todas suas exibições teatrais de humildade, mesmo com outros patrões. Não tolerava injustiça dos patrões, mostrando sua irritação quando alguém se atrevia a sugerir que controlava a cena:

A senhorita M. disse que era a melhor juíza daquilo, \& eu disse, "Não, senhora, a senhora não pode falar do meu trabalho tão bem como eu". Suponho que ela percebeu meu temperamento forte, como eu percebi o dela, pois ela disse, "Hannah, você está esquecendo seu lugar". Eu disse, "Não senhora, não estou". ${ }^{65}$

Munby também era objeto de sua ira quando tentava "brincar" com sua paciência: "É como se o ressentimento \& o orgulho crescessem dentro de mim, \& e não me deixassem falar nem ser agradável e boa como quero ser" ${ }^{66}$

${ }^{65}$ ID., IB., p. 164

${ }^{66}$ ID., IB., p. 176. 
Couro imperial

Mesmo assim, Munby gostava de se permitir a fantasia de que só ele era o senhor de seus jogos, uma arrogância que se tornou uma fonte de conflito entre eles por toda a vida. Muitas vezes ele tentava insistir no controle completo sobre Cullwick; e ela sempre resistia. Um desses desentendimentos quase levou ao rompimento definitivo. Cullwick estava nos aposentos de Munby trabalhando como sua governanta e não sabia que um menino estava na escada. Então, quando Munby insistiu que o chamasse de "Senhor", e subiu para tocar a campainha para chamá-la, explodiu em fúria contra sua violação das regras e a mudança unilateral do roteiro. "Eu pensei, Bem isso de fato é uma exibição, $\&$ voei pela escada com minha fúria no máximo grau, \& Munby começou a questionar-me por não chamá-lo de "Senhor", pois o menino estava vendo... De modo que eu estava encolerizada". Munby tinha dessacralizado seus rituais secretos, violando brutalmente os limites entre o teatro e a realidade e confundindo a submissão cerimonial de Cullwick com uma submissão real. $\mathrm{O}$ encanto mágico foi quebrado e Cullwick o ameaçou com um ultimato: "Disse-lhe que se me provocasse outra vez desse jeito eu o deixaria, fosse casada ou não, pois não ligo para isso".

O trágico paradoxo da vida de Cullwick, entretanto, era que Munby lhe concedia o tão desejado reconhecimento do valor de classe trabalhadora, mas apenas em privado. Escolher o reconhecimento público como sua esposa (como ele queria) significava negar sua capacidade de trabalho, perdendo sua mobilidade social e barganhando sua independência de espírito. Cullwick nunca escapou a esse paradoxo social, que podia ser negociado mas nunca resolvido individualmente. Dessa maneira, o S/M leva ao limite a promessa liberal da resolução social pela agência individual.

Para entender melhor o sentido do fetichismo de Cullwick, é necessário explorar o contexto social em que encontrava significado e contra o qual se colocava com teimosa recusa. Esse contexto foi a invenção histórica do labor do lazer e da empregada invisível. 
Anne McClintock

\section{O trabalho do lazer}

As mulheres sempre trabalharam nem sempre trabalharam por salário Sophonsiba Beckenridge

Num século obcecado com o trabalho da mulher, surgiu a idéia da mulher ociosa. O lugar-comum mostra a vida da mulher vitoriana como uma orgia de ócio. Nalgum ponto no século dezoito, diz a estória, a roca $e$ o fuso foram tirados de suas mãos $e$ todos os intensos labores do século anterior - a confecção de velas e de sabão, a feitura de roupas e de chapéus, o trançado de palha e o crochê de rendas, a separação de lãs e de linho, os trabalhos com o leite e as galinhas - foram removidos passo a passo para as manufaturas. ${ }^{67}$ Ao final do século dezoito, escreve Wanda Neff, "o triunfo da mulher inútil era completo" ${ }^{68}$ Roubada de seu trabalho produtivo, a mulher de classe média se tornou adequada, é o que se diz, apenas a um lugar ornamental na sociedade. ${ }^{69} \mathrm{Ali}$, lindamente envolta pelo suave perfume das aquarelas e bordados leves, ela viveria apenas para adornar a ambição mundana do marido, o fabricante, o banqueiro urbano, o armador. ${ }^{70}$ Abrigada depois do casamento num ninho de conforto, ela simplesmente

${ }^{67}$ NeFF, Wanda Fraiken. Victorian Working Women: an Historical and Lterary Study of Women in British Industries and Professions, 1832-1850. N.Y., Columbia University Press, 1929.

${ }^{68}$ ID., IB., p. 186.

69 "Expulsa dos laticínios, das confecções, dos estoques, das destilarias, do galinheiro, da horta e do pomar", como diz Margaretta Grey, ela fechou as portas ao trabalho social e foi para o andar superior pelo resto do século, para descansar languidamente nos sofás, com uma arrogância surda. apud Pearsall, p.97.

${ }^{70}$ NefF, W. F. Victorian Working Women... Op. cit., p.187. Seu dever, se lembrarmos o famoso e perturbador ensaio de Ruskin, Of Queens Gardens, "era simplesmente ajudar na ordenação, no conforto e no adorno da casa". In: CoOK, E. T. e Wedderburn, A. D. O. (eds.) The Complete Works of John Ruskin. London, vol. 18, 1902-1912, p. 122. 
Couro imperial

trocara a inutilidade temporária pela permanente. ${ }^{71}$ Encerrada em seu "frio sepulcro de vergonha", a virgem na sala íntima enrubescia à vista das pernas de mesa e se retraía aos prazeres do corpo. Seu sonolento torpor era apenas roçado por indisposições histéricas, por desfalecimentos e por um sem número de criados enfadonhos. ${ }^{72}$ Frígida, neurastênica ou ornamental; murchando na estufa da domesticidade vitoriana; terrivelmente preocupada com ninharias; dada à irracionalidade e à histeria; definhando de tédio; incapaz de constância, decisão ou estatura, a mulher de classe média era, até recentemente, consistentemente menosprezada, $e$ sua vida, como observa Patricia Branca, era considerada como um "feixe de trivialidades".

Nesse momento nasciam o que Nancy Armstrong chama de "homem econômico" e "mulher doméstica". ${ }^{73}$ Segregado na ética da pureza, o "anjo na casa" de Coventry Patmore parecia flutuar numa esfera separada. ${ }^{74}$ No tumulto do mercado comercial, o homem econômico parecia jogar seu destino como o ator público

${ }^{71}$ Baldwin Brown exortava as mulheres a confortar seus homens "cansados pelo mundo" num lar que fosse "como um pedaço do céu, iluminado, sereno, calmo, alegre, num mundo não celestial." Brown, Baldwin. Young Men and Maidens: a Pastoral for the Tmes. London, Hodder e Stoughton, 1871, pp.38-39.

${ }^{72}$ Hood, E.P. The Age and its Architects: Ten Chapters on the English Peolple. In: Relation to the Times. London, 1850, 1852, apud HougHTon, Walter. The Victorian Frame of Mind. New Haven, Yale University Press, 1957, p.354.

${ }^{73}$ Armstrong, Nancy. The Rise of the Domestic Woman. In: Armstrong, Nancy e TENNENHOUSE, Leonard. (eds.) The Ideology of Conduct: Essays in Literature and the History of Sexuality. London, Methuen, 1987.

${ }^{74} \mathrm{O}$ lar, conforme imaginado pela evocação exemplar e rósea de Ruskin, tornouse "o lugar da paz; o abrigo, não apenas de toda injúria, mas de todo terror, dúvida e facciosismo." O abraço fortificado do "muro coberto de rosas" de Ruskin era uma barricada para o coração contra os ruídos violentos $e$ sanguinolentos do comércio. Reclusa nesse "lugar sagrado, um templo de vestais", a verdadeira feminilidade oferecia "um centro de ordem, o bálsamo contra a angústia, e o espelho da beleza." Além do muro da domesticidade, "a grama selvagem que se estende até o horizonte está partida pela agonia dos homens e marcada pela trilha de seu sangue vital." RuSkIN. Of Queens Gardens. Op. cit., pp.60, 72, 76. 
e o autor da história: "acima de tudo o fazedor, o criador, o descobridor, o defensor". A mulher doméstica foi adequada a seu destino como doce preservadora e confortadora, veículo e salvaguarda da tradição. Até a década de 1970, a maioria dos críticos simplesmente repetiu literalmente esse retrato fictício da flor esmagada da feminilidade de classe média, tomando os escritores vitorianos ao pé da letra e aceitando seus retratos como documentários. ${ }^{75}$

Por décadas, portanto, supôs-se que o signo visível da dona de casa vitoriana de classe média fosse o do lazer. ${ }^{76}$ Tinha a mesma amplitude a suposição de que a "típica" mulher de classe

\footnotetext{
${ }^{75}$ NefF, W. F. Victorian Working Women... Op. cit., p.187. Neff resume a visão dominante: "A prática do ócio feminino espalhou-se pela classe média até que o trabalho se tornasse uma infelicidade e uma desgraça para as mulheres." Sir Charles Petrie a acompanha obedientemente, ainda que não tenha se dado ao trabalho de citar sua fonte: "O fato de um homem manter suas mulheres no ócio tornou-se o sinal da sua importância... O exemplo espalhou-se pela classe media até que o trabalho se tornasse uma infelicidade e uma desgraça para as mulheres." Petrie conclui: "Poucos aspectos da sociedade moderna estão tão bem documentados quanto a mulher da classe media do século dezenove, bastante tematizado pela ficção contemporânea... A heroína vitoriana é quase um produto padrão." The Victorians. New York, Longmans, 1961. O influente Prosperity and Parenthood apenas expandiu a idéia de que a própria formação da identidade da classe média dependeu da cópia da "paraphernalia de status" da classe alta, no centro da qual estava a "mulher ociosa", e foi seguido nisso por um crítico após o outro. BANKS, J. A. Prosperity and Parenthood: a Study of Family Planning Among the Victorian Middle Classes. London, Routledge, 1954.

76 "O estilo de vida da senhora burguesa", como diz Jeffrey Weeks, "foi obtido às custas de uma ampla classe de empregados." WEEKS, Jeffrey. Sex, Politics and Society: the Regulation of Sexuality since 1800. London, Longman, 1981, p.40. A manutenção de empregados foi vista por muitos historiadores como a fonte principal da identidade da classe média. Em 1899, Seebohm Rowtree usou "a manutenção ou não de empregados domésticos" como linha divisória entre "as classes trabalhadoras e aquelas de um escalão mais alto." apud HoRN, Pamela. The Rise and Fall of the Victorian servant. Strod, Alan Sutton, 1986, p.17. Como dizia a esposa de um cirurgião inglês: "Não devo fazer o trabalho doméstico ou levar o bebê para passear: eu perderia status. Precisamos manter uma empregada." ID., IB., p.18. J.F.C. Harrison concorda em que manter empregados " estava no próprio coração da idéia de classe."
} 
Couro imperial

média era deixada livre para gozar de seu conspícuo lazer pelo emprego de pelo menos três criados domésticos em seu lar. ${ }^{77}$ Por suposição comum, um lar típico de classe média não estava completo sem pelo menos três domésticas pagas. ${ }^{78}$ Mas Patricia Branca, somando os salários médios de cozinheira, copeira, arrumadeira ou ama, calcula que a renda familiar requerida para empregar essa "trindade necessária" correspondia apenas à ínfima elite de classe alta e média alta. A maioria das mulheres de classe média (ela mesma uma ampla categoria em constante mudança, ainda em formação) teria que se contentar em ter, na melhor das hipóteses, uma única menina inexperiente cuja vida daria possivelmente uma crônica de trabalho interminável e salário lamentável. ${ }^{79}$ As mulheres dos pequenos comerciantes, escreventes, merceeiros e encanadores teriam que se contentar com os serviços de uma empregada para tudo. Talvez as mulheres dos profissionais pudessem contar com os serviços de duas criadas pagas, enquanto os médicos, clérigos, gerentes de bancos $e$ empreendedores de sucesso poderiam, ao final do período vitoriano, empregar três. ${ }^{80}$ Pode-se afirmar que em realidade não

${ }^{77}$ Em 1975, Patricia Branca começou a questionar a imagem da mulher de classe média como "uma estranha peça de museu", reduzida a alvo da crítica ou a objeto de uma simpatia benevolente. Analisando criticamente manuais de economia doméstica, de cozinha, de cuidados com as crianças e de cuidados com a casa, Branca começou a levantar questões a respeito da verossimilhança da mulher ociosa da ficção e da autoridade das referências das fontes dos críticos. BRANCA, Patrícia. Silent Ssterhood: Middle-Class Women in Victorian home. London, Croom Helm, 1975.

${ }^{78}$ ID., IB., p. 186.

${ }^{79} \mathrm{Na}$ Last Chronicle of Barset, de Anthony Trollope, a família luta para conservar uma empregada enquanto seus tapetes estão em frangalhos e a mobília quebrada.

${ }^{80}$ Integrantes privilegiados da alta classe média, tais como grandes fazendeiros ou párocos e reitores importantes, podiam ter a seu serviço um cocheiro ou um jardineiro, uma cozinheira, uma babá e uma dupla de empregadas domésticas, ao passo que as classes que tradicionalmente mantinham empregados, a aristocracia e os grandes proprietários de terra, freqüentemente tinham um 
existiam nem a típica dama burguesa nem a típica criada doméstica. Muito pouca atenção foi dada à discrepância entre os retratos vitorianos de mulheres (em sua maioria de alta classe média) e a miríade de situações domésticas medianas que assumiam forma contraditória ao longo do século. ${ }^{81}$

Embora historiadores contemporâneos tenham observado o valor simbólico da classe das empregadas na formação da identidade da classe média, poucos reconheceram o valor econômico da classe das empregadas domésticas como trabalho. ${ }^{82}$ $\mathrm{O}$ que estou sugerindo é que - com exceção da ínfima elite verdadeiramente apta ao lazer - o ócio era menos um regime de inércia imposto às mofinas esposas e filhas da classe média do que um laborioso e demorado papel característico desempenhado por mulheres que queriam pertencer à classe "respeitável". Para a maioria das mulheres cujos maridos ou pais não podiam pagar criadagem suficiente para o ócio genuíno, o trabalho doméstico tinha que ser acompanhado pelo esforço sem precedente histórico de tornar invisivel cada sinal desse trabalho. A limpeza e o gerenciamento de suas grandes casas construídas de maneira ineficiente exigiam uma imensa quantidade de trabalho e energia da maioria das mulheres comuns. Mas a vocação de dona-de-casa era precisamente ocultar esse trabalho.

A posição de dona-de-casa se tornou uma carreira em atos invisíveis. A vocação de uma esposa era não só criar uma família limpa e produtiva mas também assegurar o habilidoso

"exército" de servidores, tão grande quanto "uma pequena vila". BRANCA, P. Silent Ssterhood... Op. cit., p.20.

${ }^{81}$ Ver Davidoff, L. e HaLl, C. Family Fortunes... Op. cit.

${ }^{82}$ E. P. Thompson, por exemplo, observa que, com exceção do trabalho agrícola, o trabalho doméstico era a categoria que agrupava a maioria das mulheres; no entanto ele não dá qualquer atenção à história $e$ às condições desse trabalho. THOMPSON, E. P. The Making of the English Working Class. New York, Vintage, 1966. Ver a excelente crítica de Joan Scott à política de gênero de Thompson em ScotT, Joan. Gender and the Politics of History. New York, Columbia University Press, 1988, cap.4. 
Couro imperial

ocultamento de cada sinal de seu trabalho. Sua vida se desenvolvia em torno do imperativo contraditório de trabalhar e tornar invisível esse trabalho. Seu sucesso como esposa dependia de sua habilidade na arte de ao mesmo tempo trabalhar e parecer não trabalhar. Seu jogo de salão - o momento ritual de aparecer fresca, calma e ociosa diante do olhar do marido, pai e visitantes era uma performance teatral de lazer, a negação cerimonial de seu trabalho. Para a maioria das mulheres das ainda desorganizadas classes médias, sugiro, o ócio era menos uma ausência de trabalho do que um trabalho de lazer.

A arquitetura das casas de classe média girava em torno desse paradoxo. A sala de estar marcava o limiar entre o privado $e$ o público, servindo como espaço doméstico para a espetacular metamorfose (pública) do trabalho feminino em lazer feminino. A lida matinal atendia ao requisito de ser vista - ociosa e despida dos sinais indicadores de trabalho. Como zona limítrofe, a sala de estar também se tornou o espaço doméstico de exibição do fetichismo da mercadoria. A sala servia para exibir ostensivamente os "melhores" objetos da família: o valor de uso foi transformado em valor de exibição. Em casas de baixa classe média, a ansiosa exibição de "boa" prata, "boa" porcelana e "bons" móveis (mercadorias com valor de exibição mais que de uso) escassamente ocultavam o custo, o excesso de trabalho $e$ a ansiedade subjacentes ao espetáculo mercantil do lazer feminino $e$ da capacidade de compra masculina. Uma dona-de-casa fresca e bonita à cabeceira da mesa negava as horas de trabalho ansiosas e suadas - cozinhar, limpar e polir - mesmo com a ajuda de uma criada com excesso de trabalho. O dilema dessas mulheres era que quanto mais convincente fosse sua performance do trabalho do lazer, maior era seu prestígio. Mas esse prestígio era conquistado não pelo próprio ócio, mas por uma laboriosa imitação do ócio.

Certamente o que importava não era o espetáculo do lazer em si mesmo, mas a subestimação do trabalho feminino que o 
espetáculo alcançava. ${ }^{83}$ Daí o fetiche vitoriano das mãos, pois as mãos podiam denunciar traços de trabalho feminino de modo mais visível que um avental lavável ou luvas descartáveis. As donas-de-casa eram aconselhadas a esfregar as mãos à noite com toucinho e a usar luvas na cama para evitar manchas de gordura nos lençóis, imperativo que revelava o embaraço tão fundamental com o trabalho feminino que tinha que continuar mesmo durante o sono.

\section{A criada invisível}

É claro que o maior peso do apagamento do trabalho doméstico recaía sobre as criadas. O trabalho do lazer da donade-casa correspondia ao trabalho da invisibilidade da criada. As criadas tinham ordem de se manter fora da vista, fazendo o trabalho mais sujo antes da alvorada ou tarde da noite, escondendo-se dos patrões, ficando no labirinto das entradas dos fundos, ficando, a todo custo, fora da vista. Se tivessem que aparecer diante dos seus "superiores" para atender à campainha dos senhores ou abrir a porta para algum visitante, eram obrigadas a trocar-se instantaneamente, deixando as roupas sujas de trabalho e vestindo roupas limpas, brancas e frescas - uma metamorfose ritual que era um ensaio da demorada transferência do trabalho doméstico do domínio do visto para o do não visto. ${ }^{84}$ O fetiche das roupas limpas é indicador do esforço sistemático de tirar de vista quaisquer traços visíveis do trabalho doméstico. As luvas brancas da governanta, o avental branco da criada, as mangas brancas da ama eram emblemas da contradição entre o trabalho feminino pago e o trabalho feminino não pago [Figs.3.193.21]. Ao mesmo tempo, a miríade de ferramentas e tecnologias do trabalho - baldes, vassouras, escovas, cestos, ferros, utensílios

${ }^{83}$ Aqui poderíamos questionar a idéia de Irigaray da mímica como resistência. Isso pode ser o caso, às vezes, como pode não ser.

${ }^{84}$ Isto era um exaustivo agravante para trabalhadoras sobrecarregadas e uma fonte comum de queixa. DAVIDOFF, L. Class and Gender... Op. cit., p.54. 


\section{Couro imperial}

de cozinha, etc. - eram cuidadosamente mantidas fora de vista. Embora a oficina do alfaiate $e$ a ferraria fossem visivelmente indicadoras do trabalho, o trabalho doméstico das mulheres foi objeto de um dos atos de desaparecimento mais bem sucedidos da história moderna. ${ }^{85}$

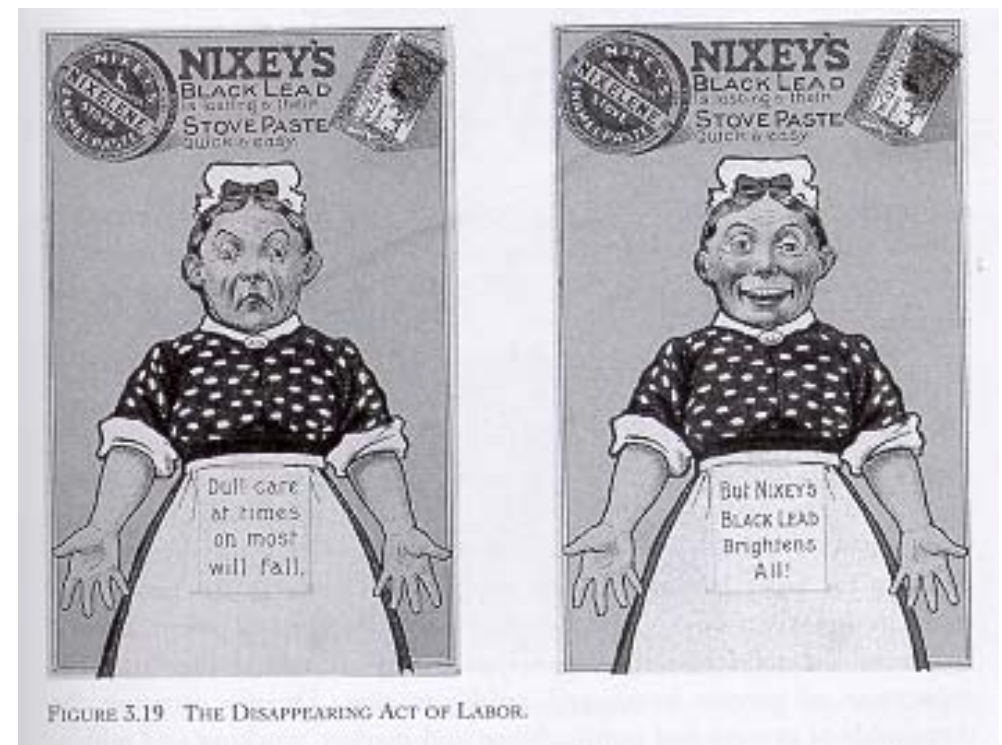

Fig.3.19. O ato do desaparecimento do trabalho.

\footnotetext{
${ }^{85}$ A própria definição de "senhora" incluía seu distanciamento do lucro. "Uma senhora... não deve trabalhar por lucro ou se envolver com qualquer ocupação comandada pelo dinheiro. As ocupações de mulheres envolvidas em qualquer negócio ou profissão... devem ser claramente explicitadas. Nenhum registro deve ser feito no caso de esposas, filhas, ou outras parentes envolvidas inteiramente com os deveres domésticos em casa." apud Burman, S. (ed.) Fit Work for Women. Op. cit., p.67.
} 


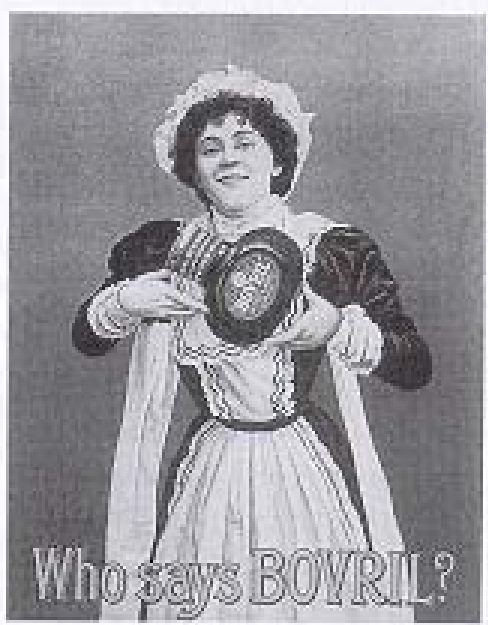

Figune 3.20 Tur WuTtexess FetrSH.

Fig.3.20. O fetiche da brancura.

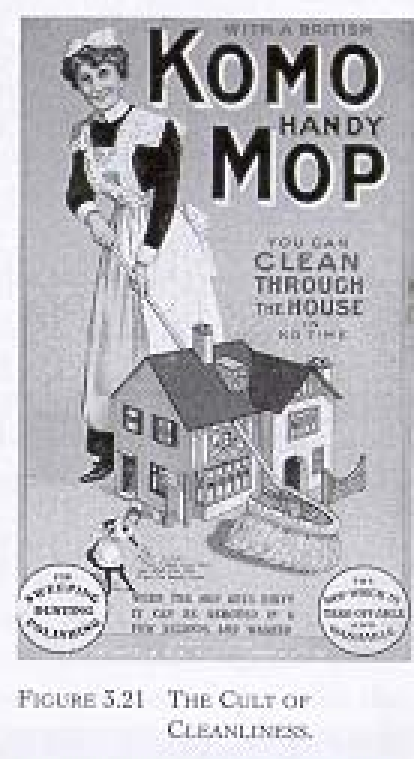

Fig.3.21. O culto da limpeza.

O trabalho do lazer da esposa e o trabalho da invisibilidade da criada seriam para negar e esconder dentro da formação da classe média o valor econômico do trabalho feminino. As criadas se tornaram assim a corporificação de uma contradição central dentro da formação industrial moderna. A separação entre o público $e$ o privado foi alcançada apenas pagando às mulheres da classe trabalhadora pelo trabalho doméstico que as esposas poderiam fazer de graça. O trabalho das criadas era indispensável ao processo de transformar a capacidade de trabalho das esposas no poder político dos maridos. Mas a figura da criada paga punha constantemente em perigo a separação "natural" entre a casa privada e o mercado público. Cruzando em silêncio as fronteiras entre o privado e o público, entre a casa e o mercado, entre a classe trabalhadora e a classe média, as criadas traziam para a casa de classe média o bafejo do mercado, o cheiro do dinheiro. 
Couro imperial

As trabalhadoras domésticas assim corporificavam uma dupla crise no valor histórico: aquela entre o trabalho pago dos homens e o trabalho não pago das mulheres e a outra entre a economia da servidão feudal e a economia industrial do salário.

Não é de surpreender que as criadas nos lares vitorianos viessem a ser representadas por imagens de desordem, contágio, doença, conflito, fúria e culpa. Por essa razão, sugiro, o espaço doméstico se tornou racializado à medida que houve apelo à retórica da degeneração para disciplinar e conter o espetáculo indecoroso do trabalho pago das mulheres.

\section{O privado, o público $e$ o fetiche das botinas}

Se Munby tinha o fetiche das mãos, Cullwick tinha o fetiche das botinas [Fig.3.22]. Não fica claro quando ela começou a contar botinas com Munby, mas numa passagem de uma terça-feira, 31 de julho de 1860, se lê: "Este é o último dia de julho. Engraxei 83 pares de botinas". As passagens são abundantes: "Tivemos uma boa tarde \& somamos as botinas". Ao longo dos anos, Cullwick engraxou uma quantidade impressionante de botinas. "Engraxei 63 pares de botinas no mês passado". Outra passagem: "Engraxei 66 pares este mês \& 937 este ano". E outra: "Este mês foram 95 pares de botinas". Outra ainda: "Isso é o mínimo por 3 ou 4 anos, devo ter engraxado mais de mil por ano" ${ }^{86}$ E Cullwick fazia esse trabalho sem ser vista, antes que a família acordasse. Quando estava com Munby convertia o trabalho da invisibilidade num teatro de exibição, transformando o que Barthes chama de "obsessão enumerativa" e o fetiche da limpeza num delírio do coração. ${ }^{87}$

${ }^{86}$ STANLEY, L. The Diaries of Hannah Cullwick... Op. cit., pp.110, 116, 147.

${ }^{87}$ BARTHES, Roland. Sade, Fourier, Loyola. New York, Farrar, Starus and Giroux, 1976. 
Anne McClintock

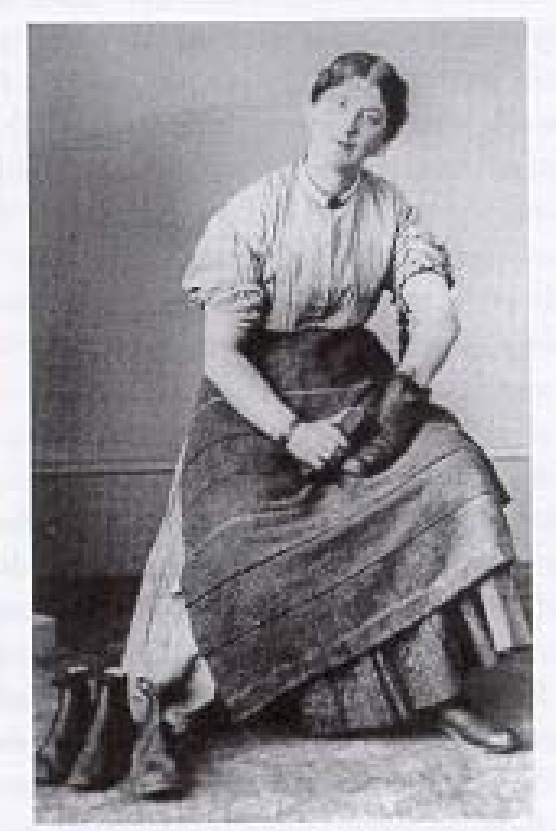

FIGURE 3.22 THE BOOT Fr.msh.

Fig. 3.22. O fetiche das botinas

É lugar comum notar o surgimento histórico da distinção entre o público e o privado no século dezenove. No entanto, a separação, ainda que decisiva, não aconteceu do dia para a noite, nem naturalmente. Ao final do século dezessete, novas formas de dinheiro extraídas das minas e fazendas imperiais tinham começado a inundar a agricultura e a indústria feudais $e$, ao longo do século seguinte, armadores, industriais, banqueiros $e$ profissionais, encorajados pelo lucro imperial, começaram a definir novas formas de dominação legítima fora da elite familiar tradicional. ${ }^{88} \mathrm{O}$ velho sistema feudal baseado em laços de

${ }^{88}$ PeRKIN, H. The Origins of Modern English Society, 1780-1880. London, Routledge \& Kegan paul, 1969. 
Couro imperial

parentesco, guildas fraternais e descendência patrilinear - isto é, na família patriarcal proprietária de terras - foi substituído por um sistema comercial baseado em relações não familiares, embora ainda firmemente patriarcais.

Não havia lei que impedisse que os novos homens do comércio abrissem caminho para os mais altos escalóes do poder social, o que gradualmente fizeram. Não havia tampouco lei que impedisse que as mulheres desses homens também chegassem a algum poder. Mas estas não o fizeram. Como observa Catherine Hall: "Num nível, a exclusão das mulheres de classe média do mundo público da política não é surpreendente" ${ }^{89}$ As barreiras tradicionais contra a participação das mulheres na política eram muitas, $e$ assim as mulheres nunca tiveram papel muito ativo na esfera política. Mas, como também observa Hall, isso também valia para os homens de classe média. Por que os homens de classe média lograram alcançar o poder e as mulheres não?

O processo da definição do espaço político público como masculino e não feminino não aconteceu simplesmente "por acaso". ${ }^{90}$ Enquanto achavam seus meios de acesso ao poder, os novos profissionais e comerciantes deliberadamente excluíam as mulheres de classe média dos clubes e tabernas, das lojas maçônicas e das organizações financeiras, das salas comerciais dos pubs, das reuniões e dos encontros políticos, da Câmara dos Produtores, das eleições legislativas e das universidades; em suma, de todas as instituições do poder público, que foram por isso mesmo definidas como espaços exclusivamente masculinos. ${ }^{91}$ Desde o início, a distinção entre o privado e o público (concebida

${ }^{89}$ Hall, Catherine. Private Persons versus Public Someones: Class, Gender and Politics in England, 1780-1950. In: LowELL, Terry. (ed.) British Feminist Thought: a Reader. Oxford, Basil Blackwell, 1990, p.52.

${ }^{90}$ ID., IB., p.52.

${ }^{91} \mathrm{Em} \mathrm{1832}$, o prefixo "masculino" foi pela primeira vez inserido na legislação sobre o voto, "tornando claro algo que sempre tinha sido suposto anteriormente, que, ao nomear os proprietários como os que tinham direito a voto, tratava-se de homens com propriedades, não de mulheres.” ID., IB., p.52. 
como um fato decorrente do progresso natural) foi resultado de um regime sistemático de deslocamento e despossessão, não só das mulheres, mas também dos homens europeus sem propriedades.

No século dezenove aconteceu uma grande transformação quando os homens de classe média remodelaram o espaço urbano para separar, como se fosse natural, a domesticidade da indústria, o mercado da família. Lenta mas firmemente, os industriais mudaram suas casas para longe das fábricas, os comerciantes deixaram de morar no segundo andar de suas lojas, os banqueiros montaram casas bancárias separadas e nasceram os subúrbios. A aprovação dos Company Acts de 1856-1862 finalmente libertaram o comércio do parentesco e a separação histórica entre o domínio público dos negócios e o domínio privado da domesticidade passou a existir de fato. Pela primeira vez, as relações políticas (dos homens) foram completamente libertadas das restrições do parentesco, criando, como se pelo direito natural, as esferas separadas do homem econômico e da mulher doméstica. Pelo menos na ideologia, as casas da classe média vitoriana passaram a ser emblemas de uma esfera distinta naturalmente separada do comércio público e por isso além dos princípios abstratos do mercado e da economia liberal e do regime de racionalidade.

Mas não se deu atenção suficiente à transformação das casas durante esse período $e$ ao importante papel que o culto da domesticidade desempenhou na formação da incipiente classe média. E há considerável evidência de que as mulheres estavam central, ainda que contraditoriamente, implicadas no surgimento da racionalidade liberal. Davidoff argumentou de maneira brilhante que o século dezenove foi palco não só da crescente racionalização do trabalho nas fábricas mas também da crescente racionalização do regime doméstico. ${ }^{92}$ Se as mulheres, assim como os primeiros operários fabris, foram as primeiras a ser postas sob o

92 DAVIDOFF, L. The Rationalization of Housework... Op. cit., pp.59-94. 
Couro imperial

domínio da racionalidade no mercado, elas também foram as primeiras a participarem da racionalização do lar. Entretanto, excluídas do poder público pela teoria liberal clássica masculina, assim como por determinações legais e econômicas, as mulheres tinham uma relação difícil e contraditória com a racionalização da domesticidade.

\section{A racionalização da domesticidade}

Nancy Armstrong argumentou que os livros de conduta $e$ manuais domésticos do século dezoito revelam uma contradição de proporções históricas. Os livros eram escritos como se se dirigissem a um amplo conjunto de leitores com objetivos sociais consistentes - uma classe média que ainda não existia. $\mathrm{O}$ novo gênero de livro de conduta feminino, diz ela, implicava "a presença de uma classe média unificada num momento em que outras representações do mundo social sugerem que tal classe não existia". ${ }^{93} \mathrm{O}$ que isso sugere é que as mulheres desempenhavam um papel muito mais importante na formação da identidade da classe média do que o que lhes tem sido atribuído. O culto da domesticidade foi crucial na medida em que ajudou a moldar a identidade de uma grande classe de pessoas (até então separadas) com claras filiações, fronteiras bem estabelecidas e valores separados - organizando-as em torno dos valores domésticos maiores da monogamia, da poupança, da ordem, da acumulação, da classificação, da quantificação e da regulação - os valores da racionalidade liberal através dos quais as desunidas classes médias moldaram o aparecimento de uma identidade única de classe.

$\mathrm{O}$ que era específico da racionalidade, na forma que assumiu no século dezenove, era sua dedicação exclusiva aos princípios da acumulação de capital para a expansão comercial. ${ }^{94}$

${ }^{93}$ ARMSTRONG, N. The Rise of the Domestic Woman... Op. cit., pp.96-141.

${ }^{94}$ WeBER, Max. The Protestant Ethic and the Spirit of Capitalism. London, Unwin University Books, 1971, p.335. Apud DAVIDOFF, L. The Rationalization of Housework... Op. cit. As virtudes da economia doméstica racionalizada 
A expansão plena do comércio imperial não seria possível sem sistemas elaborados de contabilidade racional - levantamentos, mapas, medição e quantificação - organizados, em torno do meio abstrato do dinheiro, na ciência global da superfície. Em meados do século dezenove, o domínio doméstico, em vez de ser abstraído do mercado racional, tornou-se uma arena indispensável para a criação, alimentação e incorporação desses valores. O culto da racionalidade industrial e o culto da domesticidade formavam uma aliança crucial, ainda que oculta.

A determinação da classe média em identificar a felicidade com a ordem racional e a clara marcação de fronteiras se manifestavam em regras precisas não só para a composição da esfera pública, mas também para a do espaço doméstico. ${ }^{95}$ Arranjos domiciliares tiveram lugar gradativamente em torno a uma geometria de extrema separação e especialização que passou a disciplinar todos os aspectos da vida quotidiana. O espaço doméstico era concebido como uma hierarquia de fronteiras especializadas e distintas que precisavam de policiamento constante e escrupuloso.

As fronteiras espaciais foram sendo reordenadas à medida que o grande salão comum medieval era substituído por peças menores e especializadas. Em meados do século dezenove, o que Barthes chamou de "prazer sensual na classificação" dominava o espaço doméstico - na rotulação das garrafas, na cuidadosa marcação de lençóis e roupas, na manutenção escrupulosa dos livros de visitas, na mensuração meticulosa da comida, na estrita anotação nos livros de contas. ${ }^{96}$ Utensílios tecnologias e horários especializados foram desenvolvidos para diferentes estágios da

remontam à moralidade do cultivo e da criação romanas e aparecem outra vez no monasticismo europeu $e$, de novo, em tratados puritanos e não conformistas. Como diz Weber, "A Reforma tirou o ascetismo cristão e seus hábitos metódicos dos monastérios e os colocou a serviço da vida ativa no mundo."

${ }^{95}$ Davidoff, L. e Hall, C. Family Fortunes... Op. cit.

${ }^{96}$ BARTHES, R. Sade, Fourier, Loyola. Op. cit., p.3. 
Couro imperial

preparação da comida $e$ do ato de comer. O fetiche da mensuração racional levou a um aumento no uso de pesos e medidas. A comida era servida obedecendo a horários rígidos, anunciados pelo toque de campainhas. Em lugar da mistura do doce e do salgado e do quente e do frio outrora apresentados a um só tempo, as refeições passaram a seguir estritas regras de seqüência, cada prato seguindo o anterior com o decoro apropriado ao progresso linear e racional.

O espaço doméstico foi progressivamente disciplinado pela arrumação e ordenamento obsessivos de móveis e ornamentos. O tempo foi racionalizado: a carga de trabalho dos empregados e os roteiros diários das crianças seguiam rotinas e horários estritos. A rotina da limpeza foi dividida em calendários cada vez mais racionalizados e rígidos: lavar roupas na segunda, passar a ferro na terça, polir os móveis na quarta, e assim por diante. O próprio dia doméstico era medido em unidades mecânicas, marcadas pelo toque dos relógios e o soar meticuloso das campainhas. O relógio presidia a vida do lar, representando com perfeição o fetiche vitoriano da medida, da ordem e da fronteira. ${ }^{97} \mathrm{Em}$ suma, o culto da domesticidade se tornara uma arena crucial para a racionalização da identidade e dos valores da classe média em formação.

Sabemos muito pouco sobre o papel do trabalho, das atitudes, da atuação e dos dilemas das mulheres nesse processo. Sabemos ainda menos sobre a maneira como as mulheres da classe trabalhadora negociavam, se opunham ou apropriavam o culto da domesticidade e a racionalização do lar. Os diários de Cullwick, sugiro, oferecem uma visão rara e importante dessas dinâmicas, mais valiosa ainda porque exprime uma perspectiva da classe trabalhadora. Se, como me parece, uma função central da racionalidade liberal e do culto da domesticidade era negar o valor

${ }^{97}$ Um ditado popular expressava de forma eloqüente a contaminação do tempo doméstico pelas medidas racionais e pelo capitalismo: "Perdidas ontem, em algum momento entre o nascer e o por do sol/ duas horas de ouro, cada uma com sessenta minutos de diamantes." 
social e econômico do trabalho doméstico e manual das mulheres, os diários de Cullwick fornecem o notável registro da reiterada tentativa, por parte de uma mulher da classe trabalhadora, de negociar e acomodar-se à racionalização do trabalho doméstico, sem deixar de fazer precisamente aquilo que o racionalismo liberal proibia: insistir teimosamente no visível valor social e econômico de sua capacidade de trabalho. Os escritos de Cullwick e seus rituais fetichistas revelam em vinhetas $e$ indícios algumas das contradições críticas que levam o discurso da racionalidade e o culto da domesticidade a seu limite conceitual. De fato, seus diários revelam que o fetichismo, longe de ser a antítese do racionalismo e do progresso como incansavelmente denunciado, passou a informar o culto doméstico da racionalidade como sua lógica central. Como, então, dar conta dos rituais de contagem de Cullwick?

\section{A domesticidade $e$ o fetiche da contagem de botinas}

É adequado que Cullwick tenha registrado sua vida $e$ trabalho num diário, que é o gênero literário apropriado à lógica do individualismo linear e racional e à idéia de progresso. No diário, o progresso é visto como o desenvolvimento linear e medido do indivíduo privado. ${ }^{98}$ No entanto, ele também é testemunha de uma contradição, pois o diário, possivelmente a mais privada das formas literárias, deu origem no século dezoito à novela, a mais pública das formas literárias. O diário de Cullwick não é exceção, pois foi escrito como documento privado, mas destinado a ser lido por Munby. De fato, o diário de Cullwick como um todo é plenamente expressivo da irracionalidade fetichista que deu forma ao culto da domesticidade pela classe média.

\footnotetext{
98 O diário surgiu no século dezoito, ordenando o tempo não mais de acordo com o ritmo agrícola do sol e da lua, ou com rituais de colheita e de estações do ano, mas conforme as regras mecanicamente mensuradas da indústria racional.
} 
Couro imperial

Se o diário como gênero se dedica à idéia do indivíduo, a sintaxe dos primeiros diários de Cullwick é testemunho de um sumiço: falta o soberano "eu" da subjetividade individual. Suas frases truncadas e mutiladas são empurradas pela incansável repetição de verbos de limpeza e trabalho, sua subjetividade engolfada pelo regime dos objetos. Um dia típico de seu diário de um sábado, 14 de julho de 1860, aparece assim:

Abri os postigos \& acendi o fogão. Sacudi minhas coisas cheias de fuligem \& esvaziei o depósito. Varri e tirei o pó dos quartos \& da sala. Acendi a lareira e preparei o desjejum. Limpei 2 pares de botinas. Fiz as camas \& esvaziei os penicos. Limpei e lavei as coisas do desjejum. Limpei o tampo do fogão; limpei as facas \& preparei o almoço. Limpei tudo. Limpei a cozinha; esvaziei um cesto. Levei duas galinhas para a senhora Brewer \& e trouxe o recado. Fiz uma torta \& escolhi e estripei dois patos e os assei. Ajoelhada, limpei os degraus \& lajes. Limpei as calçadas da rua também ajoelhada. Lavei a roupa. De joelhos, limpei a despensa \& e esfreguei as mesas. Esfreguei os caminhos à volta da casa \& limpei os peitoris das janelas. Preparei o chá das 9 para o patrão \& a senhora Warwick em meus trapos, mas Ann o levou. De joelhos, limpei o chão do banheiro \& do corredor \& da lavanderia. Dei banho no cachorro \& limpei as pias. Preparei o jantar para que Ann o servisse, pois estava muito suja e cansada para subir. Tomei banho e fui para a cama sem me sentir pior que ontem. ${ }^{99}$

Nos diários de Cullwick, o inescapável imperativo de limpar e ordenar os objetos - sapatos, peitoris, facas, calçamento, armários, pratos, panelas, mesas, janelas, chãos, copos - consome as energias de sua vida num infinito de repetição sem progresso ou perfeição. Isto é o que Marx chamou de fetichismo da mercadoria: a forma social central da economia industrial através

${ }^{99}$ StANLEY, L. The Diaries of Hannah Cullwick... Op. cit., p. 91. 
da qual a relação social entre pessoas se metamorfoseia numa relação entre coisas. O domínio doméstico, longe de ser a antítese da racionalidade industrial, se revela como inteiramente estruturado pelo fetichismo da mercadoria.

O trabalho doméstico é uma semiótica da manutenção de fronteiras. Limpar não é inerentemente significativo; cria um significado pela demarcação de fronteiras. O trabalho doméstico cria valor social, separando a sujeira da higiene, a ordem da desordem, o sentido da confusão. A classe média estava preocupada com a clara demarcação do limite e a ansiedade em relação à confusão dos limites - em particular, entre o privado e o público - deu lugar a um intenso fetiche da limpeza e a uma preocupação fetichista com aquilo que o antropólogo Victor Turner chama de objetos liminares, ou de fronteira. As empregadas gastavam boa parte de seu tempo limpando objetos de fronteira - maçanetas, peitoris, degraus, calçadas, cortinas e corrimãos - não porque esses objetos fossem especialmente sujos, mas porque esfregá-los e poli-los ritualmente mantinha a fronteira entre o privado e o público e dava a esses objetos um valor de exibição enquanto marcadores de classe. Maçanetas resplandecentes, cortinas recém lavadas, peitoris impecáveis e calçadas bem esfregadas - os objetos incertos no limiar entre o privado e o público, entre o de cima e o de baixo - exprimiam vividamente a fronteira entre o lar de classe média e o mercado público. ${ }^{100}$

O fetiche de classe média da pureza das fronteiras aparecia numa fixação peculiarmente intensa na limpeza das botinas [Figs. $3.23,3.24]$. As botinas são objetos liminares, carregando traços das ruas, dos campos e dos mercados para dentro de interiores polidos, confundindo o público com o privado, o trabalho com o lazer, a limpeza com a sujeira e assim adquirindo um poder fetichista especial. Por essa razão, as criadas recebiam a tarefa especial de manter os sapatos dos patrões escrupulosamente

100 Davidoff, L. e Hall, C. Family Fortunes... Op. cit., p.382. 


\section{Couro imperial}

limpos. Ao mesmo tempo, tinham que fazer os rituais de purificação sem serem vistas, antes que as pessoas acordassem.

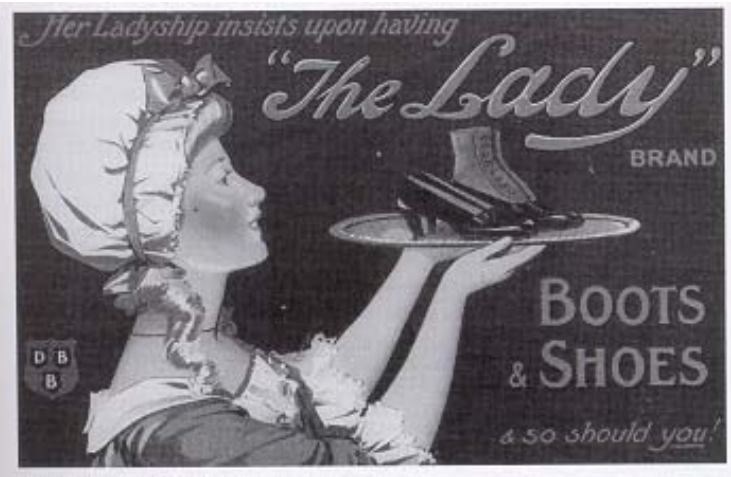

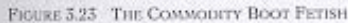

Fig. 3.23. O fetiche da mercadoria botina.

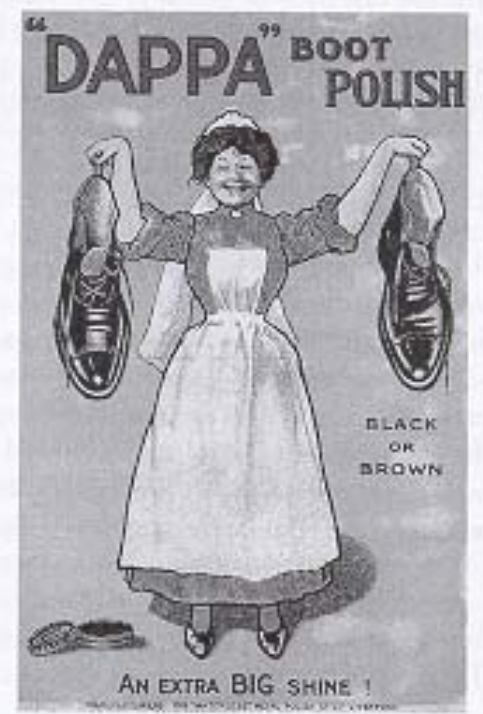

Ficuse 3.24 tur CuLt of Boundongy Pumtr.

Fig. 3.24. O culto da pureza das fronteiras. 
Cullwick e Munby parecem ter passado muitos serões contando e recontando o número extraordinário de botinas que ela limpava, num recorrente fetiche ritual que se prolongou por muitos anos. Nesses rituais de conversão, o trabalho de invisibilidade de Cullwick é convertido em reconhecimento, sua exaustão em lazer, a negação em agência. E o que é mais importante, Munby age como testemunha oficial de seus enormes trabalhos negados. Em tais momentos de delicioso reconhecimento, o "eu" da ação reaparece e a identidade dela toma forma em torno do ritual de reconhecimento. ${ }^{101}$ Ao lamber as botinas dele, além disso, como fez um par de vezes, ela transformava o trabalho secreto da limpeza das botinas numa exibição ultrajante.

Por outro lado, um paradoxo destrutivo se faz presente. $\mathrm{O}$ mais notável na diferença entre a racionalização do mercado e a racionalização do trabalho doméstico é que este último é racionalizado para tornar invisível o trabalho das mulheres negando assim seu valor econômico. A racionalização do trabalho doméstico no século dezenove envolveu maciços gastos de esforço que não foram quantificados nem calculados, dado que tal trabalho tinha que ser excluído, tanto quanto possível, do mercado racional.

A cada mês, a cada ano, a contagem de botinas de Cullwick começa outra vez - do número um. Não há progresso no trabalho doméstico, só repetição. Assim, por um lado, o fetiche das botinas demanda o reconhecimento do valor do trabalho; por outro, encena dramaticamente o fracasso do progresso doméstico. $\mathrm{O}$ fetiche das botinas revela uma obediência cega à forma racional,

101 Às vezes, para surpresa deles, Cullwick oferecia-se para limpar as botas de outros homens em público: "Posso limpar seus pés, senhor?", perguntava ela. "Eu me ajoelhava para mostrar-lhe que estava pronta a fazê-lo... ele pareceu bem surpreendido comigo \& disse 'sim, eu gostaria'. Enquanto eu limpava, ele me olhava como se mal pudesse acreditar em seus olhos." STANLEY, L. The Diaries of Hannah Cullwick... Op. cit., p. 65. Mais uma vez, Cullwick transforma trabalho proibido em espetáculo público, encontrando valor na degradação. 
Couro imperial

ao mesmo tempo em que exibe flagrantemente a lógica fetichista do próprio racionalismo. A domesticidade vitoriana ao mesmo tempo incorpora e desmente o mito iluminista do progresso racional. Não é pois de surpreender que os criados e os objetos liminares da servidão doméstica - botinas, aventais, vassouras, sabão - se tornem portadores de tamanho poder fetichista.

\section{O travestismo e o fetichismo feminino}

Uma pessoa sem roupas é uma pessoa sem linguagem.

Provérbio da África Ocidental

O grande poder de Cullwick sobre Munby se assentava em seu talento teatral para a conversão. Ao longo dos anos, ela revelou uma notável capacidade de adotar diferentes identidades sociais e diferentes roupas. Como criada, era sua profissão e orgulho encenar como naturais os ritos e exibições teatrais do status de classe média alta e de classe média. Num momento, ela estava de joelhos esfregando chãos e armários sujos, seus fortes braços imundos de água e gordura; no momento seguinte, lá estava ela, de branco fresco e seco, para atender afetadamente à porta ou ao chamado de sua patroa. Num momento, ela erguia $e$ carregava seus colegas criados em volta da mesa em frouxos de risos, ou transportava pesada bagagem, baldes de água quente ou sacos de carvão escada acima, de três em três degraus; no momento seguinte se curvava diante dos "superiores", numa mímica de servilismo e em exagerados ritos de humildade requeridos de sua situação.

Em seu relacionamento com Munby, ela transformava sua habilidade na mímica da criada em grande teatro $e$ fonte de considerável poder. Travestia-se de dama de alta classe, camponesa ou criado. Vestia-se de escravo, limpador de chaminés, anjo e ajudante, e ia ao fotógrafo para ser retratada com essas fantasias. Cortava o cabelo e vestia-se de homem $e$ 
viajava pela Europa com Munby como seu criado. Depois que se casaram, travestia-se de dama de classe alta e outra vez viajava com Munby pela Europa, desta vez como sua mulher. Munby ficava encantado com "seu talento no desempenho de cada um desses papéis".

Com seu talento excepcional para as ambigüidades da identidade, Cullwick faz parte das incontáveis mulheres que, ocultas e clandestinas, se travestem e que - segundo os éditos da tradição psicanalítica - não existem. Robert Stoller proclama firmemente que não existe a "mulher travesti": "o travestismo fetichista" nas mulheres é "tão raro que é quase inexistente". Ao contrário de Freud, Stoller diz que as mulheres "não têm o fetiche da roupa", elas simplesmente querem ser homens; desejo perfeitamente natural. ${ }^{102} \mathrm{O}$ travestismo feminino não pode ser admitido na casa da perversão, pois poria em questão a centralidade do falo como objeto do fetiche em torno do qual se supõe que o travestismo se organize. No entanto, Cullwick se travestiu ao longo de toda a vida, sem que seu fetichismo se organizasse em torno dos traumas da identidade fálica nem da transferência erótica (critico essa teoria freudiana em outro lugar), mas sim em torno das contradições históricas do trabalho das mulheres e da iconografia do império - correntes, enegrecimento, sujeira, roupas, botinas, baldes, água e escovas. Embora Cullwick bem possa ter derivado prazer erótico de seu fetichismo, entender seus rituais de travestismo e do fetiche como uma erótica da cena da castração só serviria para reduzir sua vida a uma narrativa machista do interesse sexual. Em lugar disso, sugiro que seu fetichismo era uma tentativa contínua de negociar os perigos à espreita na ocultação vitoriana do trabalho das mulheres.

O travestismo não é só um fetiche pessoal, ele é também um fenômeno histórico. O que se poderia chamar de pânico suntuário (pânico limítrofe em relação à roupa) irrompe com maior

102 STOLLER, Robert J. Observing the Erotic Imagination. New Haven, Yale University Press, 1985, p.155. 
Couro imperial

intensidade em períodos de turbulência social. No início do período moderno, as leis suntuárias na Europa e na Grã Bretanha ganharam forma em torno das reviravoltas no dinheiro e no status social engendradas pelo imperialismo. ${ }^{103}$ Como as especiarias produzidas pelos escravos das fazendas e a prata e outros metais preciosos produzidos pelos escravos das minas engendravam novas possibilidades de consumo e excedente mercantis, novas formas de dinheiro e de consumo - não mais dependentes da terra e do poder aristocrático - começaram a interferir nas velhas formas de distinção política. Essas mudanças levaram à promulgação de leis suntuárias em toda a Europa, restringindo "o uso de certas peles, tecidos e estilos a membros de classes sociais e econômicas, ordens ou 'estados' particulares". ${ }^{104}$ A roupa se tornou central para o controle das fronteiras sociais, marcando "distinções de riqueza e posição visíveis e acima de tudo legíveis dentro de uma sociedade que passava por mudanças que ameaçavam até mesmo fazer desaparecer as distinções sociais". ${ }^{105}$ O desmantelamento do regime aristocrático envolvia, em parte, o desmantelamento do corpo aristocrático como teatro de exibição suntuária e sexual.

As leis suntuárias procuraram regular as fronteiras sociais regulando a legibilidade social da roupa. ${ }^{106}$ Mas as leis suntuárias contêm um paradoxo interno, pois o fato de que a classe $e$ a posição são legíveis pelo vestir, ou não vestir, "panos de ouro, seda ou púrpura", revela a natureza inventada da distinção social, tornando visíveis tanto as origens quanto a legitimidade de

103 GARBER, Marjorie. Vested Interests: Cross-Dressing and Cultural Authority. New York, Routledge, 1991, p.21. Como ela observa (embora não discuta a relação com o império): "o termo suntuário está relacionado com 'consumption' [consumição] - perda de saúde por aqueles cuja classe ou outra designação social faz com que sua exibição pareça transgressora."

104 ID., IB., p.25.

105 ID., IB., p. 26

106 Jerdan, William. (ed.) The Rutland Papers. Camden Society Publications, \# 22, p.247 apud ID., IB., p.26. 
posição e poder. As peças de pano colorido que são os emblemas legíveis de posição estão também permanentemente sujeitas ao desarranjo $e$ ao roubo simbólico. Por essa razão, a figura do travesti passa a ser investida de um grande poder subversivo. Como diz Marjorie Garber em seu livro pioneiro, o travesti é "a figura que desorganiza". ${ }^{107}$

Garber historia de maneira brilhante o modo como "o espectro do travestismo, a intervenção estranha do travesti, marcou $e$, de fato, sobredeterminou o espaço de ansiedade a respeito de identidades fixas e mutáveis, de subjetividades permutáveis ou ausentes." 108 Garber recusa-se a aceitar a visão tradicional do travestismo como uma patologia médica ou uma anomalia biológica - a crise do travesti, argumenta ela, representa a "crise mesma da categoria". ${ }^{109}$ Dessa maneira, Garber nos estimula a ver os travestis em seus próprios termos, não como um sexo ou como um gênero, mas como apresentação da própria ambigüidade; nem como "sexo mesclado", mas sim como a corporificação e representação da contradição social. O travesti habita o limiar da distinção em categorias, desafiando "noções fáceis de binarismo e pondo em questão as categorias de 'fêmea' e "macho'."110 Garber se posiciona, assim, contra a teoria do travestismo como um progresso narrativo, que tentaria descobrir uma identidade desejada "real", seja "masculina" ou "feminina" por trás da máscara do travesti. Para ela, ao contrário, o travesti não é equivalente a um ou outro sexo mas é, antes, a figura que habita as fronteiras nas quais as oposições são perpetuamente descompostas, desorganizadas e subvertidas.

107 GARBER, M. Vested Interests... Op. cit., p.70.

108 ID., IB., p.32.

109 ID., IB., p.17.

110 ID., IB., p.10. Garber argumenta persuasivamente que críticos do travestismo, como Elaine Showalter, Stephen Greenblatt, Sandra Gilbert e Susan Gubar, tenderam, de maneiras diferentes, "partir do transsexual como travesti", buscando uma identidade de gênero verdadeira por baixo da máscara do travesti. 
Couro imperial

Não obstante, ela própria, ao universalizar todos os travestismos como uma "figura que desorganiza" $e$, ao universalizar todos os fetiches como falos ("o falo é o fetiche, o fetiche é o falo"), não pode, em última análise, explicar teoricamente a riqueza da diversidade que suas próprias histórias revelam. No âmbito da rígida moldura lacaniana à qual ela aloca todos os travestismos, a diversidade, a ambigüidade e a diferença paradoxalmente se perdem e cada travesti se torna, no nível teórico, um clone de todos os outros. Sua obediente aceitação de uma única gênese narrativa da ambigüidade fálica reduz a rica diversidade que ela historia tão bem a uma economia abstrata do um. Assim, Garber é incapaz de dar conta, teoricamente, das distinções entre práticas subversivas, conservadoras, ou radicais de travestismo e fetichismo. A diversidade desaparece na perpétua recorrência da "cena originária" única.

No mundo de lusco-fusco da ambigüidade do travestismo, Cullwick situava seu poder e seu prazer naquela zona liminar na qual as fronteiras se esfumam. Seu talento para a fantasia, o disfarce e a improvisação não era apenas uma farsa teatral; era, antes um profundo envolvimento com os éditos sociais que circunscreviam brutalmente sua vida.

Cullwick celebrava as liberdades peculiares da ambigüidade mais do que a rigidez de uma identidade. Travestis raramente buscam a segurança de uma imitação perfeita; eles desejam, sim, essa interessante incorporação que despreza o disfarce completo: "alguma coisa legível, um pé muito grande, um gesto sutil ou um timbre específico de voz." "111 Assim, quando Cullwick se disfarça e é fotografada como uma "senhora", suas mãos sujas e calosas e sua pulseira suja permanecem visíveis, de maneira não plausível sobre sua saia rodada e limpa. Sua insistente exibição das mãos e da pulseira recusa o apagamento histórico do trabalho das mulheres. Exibindo em público o signo tabu do trabalho privado das mulheres, ela põe em questão a naturalização das categorias

111 ID., IB., p.149. 
de trabalho sujo ou trabalho limpo, mulheres sujas ou mulheres limpas, insistindo em que podia "passar-se tão bem por uma ou por outra" dado que ambas eram invenções.

É extremamente importante enfatizar que Cullwick exibia transformações de raça e classe tanto quando de gênero. Travestida de "escravo", ela posava nua da cintura para cima, mostrando de maneira visível seus braços "masculinos" e seus ombros largos. Mas, ainda que pareça bem masculina, um exame mais acurado da leve curva de seus seios, meio escondidos nas sombras, sugere outras possibilidades. E, no quadro "Rossetti" (colorido à mão para Munby pelo próprio Rossetti, que declarou estar certo de que se tratava de uma "senhora"), a corrente de escrava é visível e incongruente em seu colo delicado.

Travestir-se tornou-se tão comum para Cullwick que ela escreveu em seu diário: "Chego a me esquecer se estou vestida como uma senhora ou com meu avental \& vestido de algodão na rua." ${ }^{112}$ Gautier apanha belamente o estado liminar habitado pelo travestismo, numa descrição que bem poderia ter sido escrita por Cullwick: "Eu mal me lembrava, em longos intervalos, de que era mulher; ...na verdade, não pertenço realmente a nenhum sexo... Pertenço a um terceiro sexo, um sexo à parte, que ainda não tem nome." ${ }^{113}$ De maneira análoga, Cullwick escreve a respeito de seu gênero nas casas da elite: "Eu era o homem da casa."

$\mathrm{Na}$ sua viagem à Europa como marido e mulher, ela saiu de Temple, onde vivia como a criada de Munby, com seu velho boné preto $e$ as roupas de trabalho, mudando completamente de roupa em Folkstone. Lá, no porto, onde as fronteiras da alfândega nacional permitiam a transgressão segura das convenções de classe, Cullwick vestiu seu "chapéu de feltro \& plumas de penas de galo e um véu." O chapéu ornamental e seu broche eram os signos necessários, visíveis, do lazer e riqueza de classe, e o véu era tanto uma insígnia da propriedade masculina da sexualidade

112 StAnley, L. The Diaries of Hannah Cullwick... Op. cit., p.274.

113 apud GARBER, M. Vested Interests... Op. cit., pp.329-330. 
Couro imperial

feminina quanto uma proteção contra o tempo (isto é, a desgraça de classe e raça de uma pele queimada pelo sol). Voltando da Europa, ela vestiu suas roupas antigas: "Guardei minhas melhores roupas \& vesti as minhas próprias outra vez - vestido sujo de algodão \& avental e meu boné." Suas transformações eram inteiramente convincentes: "Não fui notada chegando ou saindo de Temple". ${ }^{114}$

\section{"Tão protegida"}

\section{Casamento e resistência}

Já não há mais escravos legais, com exceção das donas-de-casa. J. S. Mill

O travestismo sinalizava a recusa de Cullwick dos papéis sociais limitados que lhe foram destinados. Vestida de homem, ela pôde viajar pela Europa com Munby sem ser questionada. Vestida como mulher da classe trabalhadora, ela entrava livremente em bares e teatros de revista, divertindo-se com lazeres da classe trabalhadora que eram proibidos às mulheres de "respeito". Ela podia andar pela rua depois de escurecer sem medo de perda de reputação ou de ameaças. Por outro lado, vestida como uma senhora, ela podia apreciar o luxo e a aventura de hotéis, lugares de férias e viagens turísticas aos quais as mulheres trabalhadoras não tinham acesso.

Por essa razão, Cullwick temia a perspectiva de se casar com Munby e, durante algum tempo, recusou enfaticamente a insistência dele para que ela aparecesse em público como sua esposa. Se, como argumenta Christine Delphy, para a maioria das mulheres "o casamento é um contrato de trabalho não remunerado", o teimoso desejo de independência de Cullwick expressava-se numa poderosa resistência, baseada em princípios,

114 StAnley, L. The Diaries of Hannah Cullwick... Op. cit., p.266. 
ao casamento. ${ }^{115}$ Já que o "laço externo" do contrato legal ameaçava transformá-la numa escrava real de Munby, Cullwick achava a perspectiva de casamento inaceitável. Se, por um lado, ela chamava Munby de "Massa" e parecia concordar simbolicamente com o dito de Rousseau de que o marido deveria ser "senhor por toda a vida", por outro, há suficiente evidência de que ela via o "senhorio" de Munby como puramente teatral. ${ }^{116}$ Por essa razão, lhe repugnava a idéia de casar com Munby e entrar para a "boa" sociedade como sua esposa. Quando Munby decidiu que já era mais que tempo de eles casarem, Cullwick não escondeu seu desgosto com isso e só consentiu quando as circunstâncias tornaram a idéia inevitável. ${ }^{117}$ Ela tinha uma profunda resistência em mudar-se para a casa de Munby e depois de quatro anos infelizes e solitários sob seu teto, ela mudou-se outra vez, contra a vontade dele, para continuar sua relação mais em seus termos do que nos dele. O casamento, com sua aparentemente permanente fixação da identidade heterossexual, parecia-lhe insuportavelmente limitador: "É parecido demais com ser uma mulher", queixou-se ela.

A pulseira de escrava de Cullwick torna visível a convergência triangular, histórica, entre esposa, criada e escrava. Uma longa e triste relação existe entre esposas e escravos. Como Engels observou, o termo "família" deriva de "famulus" que quer dizer escravo. ${ }^{118} \mathrm{O}$ estatuto das mulheres enquanto indivíduos entrou na teoria liberal clássica como um dilema central. Para que as mulheres, como os escravos $e$ as crianças, tivessem negados

115 Delphy, C. Close to Home... Op. cit., p.92.

116 RousseAu, Jean Jacques. Emile, or on Education. New York, Basic Books, 1979, p.404. [Tradução de A. Bloom.]

117 Stanley, L. The Diaries of Hannah Cullwick... Op. cit., p.188.

118 Na tradição Greco-romana, a família era, por definição, a comunidade extensa de pessoas sobre as quais o pater familias tinha jurisdição soberana, detendo direito de vida, propriedade e trabalho da esposa, escravos e crianças. A comparação entre esposas e escravos continuou a ser feita depois do final do século dezessete. Mary Astell dizia que todas "as mulheres nascem escravas". 
Couro imperial

seus direitos à liberdade e à propriedade, um trabalho ideológico precisava ser feito. A solução está na distinção entre público e privado. Os teóricos liberais clássicos definiram como político o direito de estabelecer contratos na esfera pública, mas definiram a relação conjugal como pertinente ao âmbito da natureza e, assim, além do contrato. A soberania doméstica do marido sobre a mulher e, portanto, a exclusão das mulheres do individualismo possessivo, foi justificada como derivada da lei natural, não da lei política. ${ }^{119}$ Assim, quando Munby se alegra que Cullwick tenha sido trazida a ele "por quem trouxe Eva para Adão", ela fala na linguagem apropriada dos teóricos liberais clássicos. Para Locke, a soberania de Adão em relação a Eva "tinha um fundamento na natureza". ${ }^{120}$ Em seu "Primeiro Tratado", Locke argumenta que a submissão natural de Eva é tal que "cada marido deve ordenar as coisas privadas que digam respeito a sua família como proprietário dos bens e terras existentes e estabelecer a sua vontade acima da de sua mulher em todas as coisas de seu interesse comum. ${ }^{121}$ Para Pufendorf, no entanto, o direito conjugal, ainda que adequado "à condição da natureza humana" deve ser assegurado "ou pelo seu consentimento, ou por uma guerra justa". Mas, como para Pufendorf "a coisa mais natural" é que o casamento ocorra com boa vontade, os direitos conjugais do marido se originam da "sujeição voluntária" da esposa ao "vínculo desigual" do casamento. ${ }^{122}$ Carol Pateman observa que dessas redefinições da lei do contrato emerge um paradoxo: as mulheres são por natureza tornadas incapazes de fazer contratos como iguais com os homens sob a lei política (já que as mulheres são naturalmente subordinadas); no entanto, as mulheres podem e devem fazer contratos de casamento (já que o casamento deveria ser visto como uma questão de consentimento, não de coerção). Por meio

119 PATEMAN. The Sexual contract. p.51.

120 apud ID., IB., p.52.

121 PATEMAN. The Sexual contract. Op. cit., p.53.

122 ID., IB., p. 51. 
desses debates, a teoria liberal estabeleceu uma distinção ideológica entre a liberdade individual e o direito a fazer contratos na esfera política, e a recusa do direito a tal estatuto político na esfera doméstica, conjugal. Assim, como diz Pateman, o casamento permaneceu uma anomalia legal que "mantém um estatuto natural mesmo na sociedade civil". ${ }^{123}$ A distinção inventada entre a esfera "natural" da família e a esfera "política" da sociedade civil era indispensável à formação da identidade masculina de classe média porque foi utilizada para restringir a noção liberal de individualidade soberana aos homens europeus com descendência e herança. Com o álibi da natureza imperial, mulheres, escravos, servos $e$ os colonizados poderiam ser excluídos da individualidade liberal. A emergência do indivíduo liberal racional configurou-se, assim, em torno da reinvenção da esfera doméstica com um âmbito de submissão natural, assim como o âmbito do "primitivo" era o âmbito da submissão racial natural. Domesticiadade e império se fundem como um elemento necessário na formação da imaginação liberal.

A pulseira de escrava de Cullwick era a corporificação dessas contradições. A submissão verbal, voluntária, da esposa ("Aceito") representa uma exibição cerimonial de hegemonia, pois a mulher entra "voluntariamente" numa relação social de desigualdade com seu marido, o que lhe dá, desde então, o direito legal de coerção sobre ela. Em suma, o contrato da esposa é um contrato da hegemonia para a coerção. ${ }^{124}$ A pulseira de escrava de

123 ID., IB., p.55.

124 Legalmente, as esposas eram classificadas junto com criminosos, idiotas e menores. Pela lei, a propriedade pessoal de uma mulher passava inteiramente para seu marido. Legalmente ele poderia dispor dela da maneira que quisesse. Ele poderia não deixar nada para sua esposa ou filhos em seu testamento. Se o marido morresse sem testamento, a esposa recebia, no melhor dos casos, apenas a metade. Se a mulher morresse sem testamento, toda sua propriedade ficava com ele. Uma esposa não podia fazer contratos, a não ser como agente do marido. Assim, pela lei, o casamento era equivalente ao roubo legalizado e sistemático. 
Couro imperial

Cullwick expõe uma contradição fundamental da teoria liberal clássica: as mulheres são naturalmente como escravos e, assim, não podem fazer contratos, mas as mulheres devem fazer contratos de modo a tornar-se esposas e, portanto, abdicar de seu direito a fazer contratos.

Cullwick rejeitou amargamente a sugestão benevolente de Munby de que ela deveria ser grata a ele por desposá-la:

Antes que os visitantes chegassem, Munby me mostrou uma certidão que tinha comprado - uma certidão de casamento - para mim e para ele \& disse "Isto não prova o quanto a amo \& o que você diz a respeito disso?" Disse-lhe que não tinha nada a dizer sobre isso, mas esperava que ele nunca se arrependesse disso, nem eu. Ainda que eu parecesse serena \& e tenha dito tão pouco, realmente acredito no que disse. Eu me importava muito, muito pouco com a certidão ou em ser casada. ${ }^{125}$

Ela não iria tolerar a idéia condescendente de Munby sobre seu casamento "como um prêmio para mim pois não quero nenhum prêmio", e ficou profundamente ressentida com a realidade social da certidão de casamento como sendo um "laço externo": "Parece que odeio a palavra casamento neste sentido." ${ }^{26} \mathrm{O}$ casamento de Cullwick com Munby foi em quase todos os aspectos um acúmulo de transgressões. Ao insistir em receber pagamento dele por seus serviços, ao ser contratada para trabalhar fora como quisesse, ao manter seu próprio dinheiro (ainda que pedisse a Munby que ele cuidasse dele), Cullwick colocou-se contra os éditos fundamentais das leis conjugais

125 Stanley, L. The Diaries of Hannah Cullwick... Op. cit., p.253.

126 ID., IB., p.253. A rejeição de Cullwick ao "laço externo" do casamento ecoa asperamente nas palavras de Roxana, de Daniel Defoe, cuja heroína proclama: "A própria Natureza do Contrato de Casamento era, em suma, nada mais do que abrir mão da Liberdade, da Propriedade, da Autoridade, e de tudo, para o Homem, e a Mulher era, de fato, apenas uma Mulher para sempre, isto é, uma Escrava." apud PATEMAN. The Sexual contract. Op. cit., p.120. 
vitorianas. De fato, silenciosa e teimosamente, ela pôs em prática aquilo pelo que as feministas lutaram durante o resto do século: o direito de controlar seu corpo, seu trabalho, seu dinheiro e sua liberdade reprodutiva, o que é ainda mais notável e lhe dá mais autoridade pelo fato de que isso ocorreu no contexto de uma enorme falta de autoridade social das mulheres. [Fig.3.25]

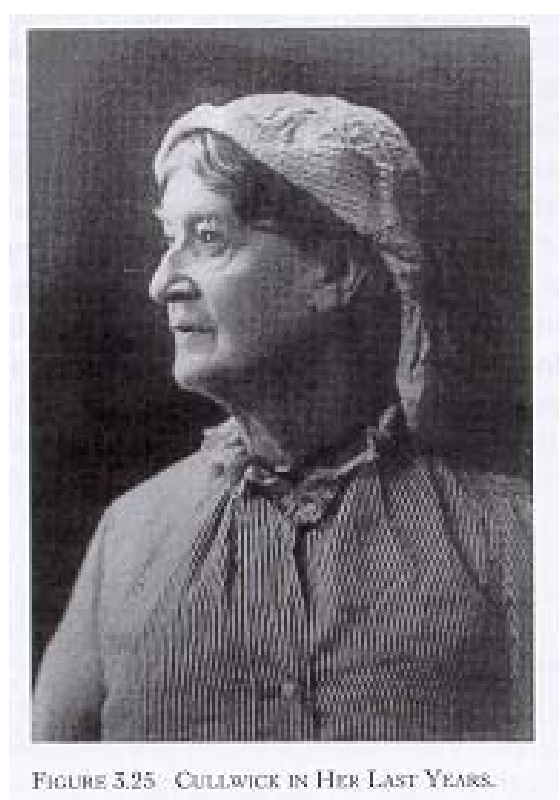

Figura.3.35. Cullwick no final de sua vida.

Vivendo como a "escrava simbólica" de Munby e, de fato, fazendo o que queria, Cullwick negociou um grau de poder que de outra maneira seria quase impossível. Vivendo independente de uma unidade doméstica conjugal, ela evitou o contrato de um casamento que a tornaria legalmente submissa a um homem da classe trabalhadora. "Decidi que era melhor \& mais seguro ser escrava de um cavalheiro, e não esposa e igual de qualquer 
Couro imperial

homem comum." 127 Seu casamento com Munby permaneceu um caso puramente oficioso, e ela nunca abriu mão de seu nome de nascimento. E, mais importante, ao recusar-se a viver abertamente como esposa, Cullwick evitou ter filhos; parece claro que ela não desejava ser mãe. Ao contrário, ela comenta apiedada a respeito de uma prima: "Fiquei feliz por não ser mãe de uma pequena família como ela... pois apesar de ser natural, dá muito trabalho \& depois que eles crescem, em geral da muita ansiedade." ${ }^{28}$ Cullwick não suportaria o tédio e a dependência de ser uma esposa nem os sacrifícios que acompanham a maternidade:

Ah Ellen - a música é agradável, \& a poltrona é agradável, mas mais do que estar com os parentes ou vestida como eles \& tudo isso, prefiro cinqüenta vezes estar preta com a limpeza das chaminés. $\mathrm{E}$, entre os dois, o que dura mais \& e o que é mais sólido \& um prazer real?

Ela preferia a liberdade do "andar de baixo" e com freqüência elogiava a liberdade de mobilidade pública que seu baixo estatuto lhe propiciava:

Posso trabalhar com calma. Posso sair e voltar quando quero... todos os anos em que caminhei por Londres ninguém nunca me faltou com o respeito, \& não creio que o façam se você estiver vestida com simplicidade \& e estiver na rua tratando de seus próprios assuntos. ${ }^{129}$

Dessa maneira complexa, o âmbito do fetichismo foi para Cullwick uma arena de contestação e de negociação. Ela reivindicou o direito de manipular os signos teatrais de rebaixamento de modo a recusar a legitimidade de seu valor como natureza. Longe de ver o casamento como presente do

27 StAnley, L. The Diaries of Hannah Cullwick... Op. cit., p.273.

128 ID., IB., p.238.

129 ID., IB., p.181. 
progresso, ela recusou a "grande idéia do século dezenove" ao escolher o valor de seu trabalho por oposição ao tédio acolchoado $e$ à servidão do casamento. Recusando-se a trocar a sua força desordeira de classe trabalhadora pelas rédeas da respeitabilidade, ela se adornou com seus próprios grilhões simbólicos, pondo em questão, de modo dramático, a narrativa vitoriana de progresso $e$ a família humana heterossexual. 